\title{
Discordant evolution of organellar genomes in peas (Pisum L.)
}

Vera S. Bogdanova ${ }^{\mathrm{a}}$, Natalia V. Shatskaya ${ }^{\mathrm{a}}$, Anatoliy V. Mglinets ${ }^{\mathrm{a}}$, Oleg E. Kosterin $^{\mathrm{a}, \mathrm{b} *}$ and Gennadiy V. Vasiliev ${ }^{\mathrm{a}}$

${ }^{a}$ Institute of Cytology and Genetics of Siberian Division of Russian Academy of Sciences, Novosibirsk, Russia

${ }^{\mathrm{b}}$ Novosibirsk State University, Novosibirsk, Russia

*corresponding author at: Institute of Cytology and Genetics of Siberian Division of Russian Academy of Sciences, Novosibirsk, Russia.

E-mail: kosterin@bionet.nsc.ru (Oleg E. Kosterin)

ORCID 0000-0001-5955-4057

(C) this manuscript is made available under the CC-BY-NC-ND 4.0 license http://creativecommons.org/licenses/by-nc-nd/4.0/

\begin{abstract}
Plastids and mitochondria have their own small genomes which do not undergo meiotic recombination and may have evolutionary fate different from each other and nuclear genome, thus highlighting interesting phenomena in plant evolution. We for the first time sequenced mitochondrial genomes of pea (Pisum L.), in 38 accessions mostly representing diverse wild germplasm from all over pea geographical range. Six structural types of pea mitochondrial genome were revealed. From the same accessions, plastid genomes were sequenced. Bayesian phylogenetic trees based on the plastid and mitochondrial genomes were compared. The topologies of these trees were highly discordant implying not less than six events of hybridisation of diverged wild peas in the past, with plastids and mitochondria differently inherited by the descendants. Such discordant inheritance of organelles is supposed to have been driven by plastid-nuclear incompatibility, known to be widespread in pea wide crosses and apparently shaping the organellar phylogenies. The topology of a phylogenetic tree based on the nucleotide sequence of a nuclear gene His 5 coding for a histone H1 subtype corresponds to the current taxonomy and resembles that based on the plastid genome. Wild peas (Pisum sativum subsp. elatius s.l.) inhabiting Southern Europe were shown to be of hybrid origin resulting from crosses of peas similar to those presently inhabiting southeast and north-east Mediterranean in broad sense.
\end{abstract}

Keywords: mitochondrial genome; plastid genome; wild peas; Pisum L.; natural hybridisation; phylogenetic trees; discordant evolution; reticulate evolution; plant microevolution 


\section{Introduction}

The genus Pisum L. (Fabaceae, Fabea) includes an ancient (Zohary \& Hopf, 2000) but still important crop, the pea (Pisum sativum L.), and its wild relatives (Maxted \& Ambrose, 2001), a potential source of genetic diversity for crop improvement. Besides, wild peas are a good model for studying microevolution being annual plants with very small populations. At the same time wild peas are still insufficiently studied and their diversity was obscured by a number of circumstances: (i) taxonomic instability of the genus (Maxted \& Ambrose, 2001; Coulot \& Rabaute, 2016; 2017), (ii) confusion of genuine wild plants with 'primitive', traditionally cultivated local landraces or feral cultivated peas; (iii) spontaneous crossing while reproduction in germplasm collections; (iv) confusion of labels and physical contamination of seeds in germplasm collections; (v) explicit or hidden duplication of accessions in different collections (Kosterin 2016; Zaytseva et al., 2017), (vi) depletion and extinction of wild pea populations due to deterioration of natural habitats (Maxted and Kell, 2009). These complications, especially (i) and (ii), eluded the interpretation of the results of repeated phylogenetic and diversity analyses (Ellis et al., 1998; Vershinin et al., 2003; Jing et al., 2005; 2007; 2010; Tar'an et al., 2005; Smýkal et al., 2017). While the methods applied were powerful in resolving clusters and evolutionary branches, their proper interpretation demanded a clear idea of the taxonomical treatments of accessions involved, their cultivation status, phenotype, ecology and geography.

Here we adopt the taxonomic system of Pisum outlined by Maxted \& Ambrose (2001). According to this generalised system, the genus embraces a clearcut wild species $P$. fulvum Sibth. et Smith from Israel, Syria, SE Turkey and Sinai Peninsula and a diverse species $P$. sativum containing both wild (conventionally considered as the subspecies P. sativum subsp. elatius (Bieb.) Aschers. et Graebn. in a broad sense) and cultivated ( $P$. sativum subsp. sativum) peas. Besides, there is a cultivated taxon from Yemen and Ethiopia, resembling $P$. sativum but scarcely reproductively compatible with it, of an equivocal rank (Kosterin, 2017; Weeden, 2018), here considered as a species P. abyssinicum.

The key feature of wild peas is dehiscing pods, providing ballistic seed dispersal (Weeden, 2007; Ambrose and Ellis, 2008; Zaytseva et al., 2017). Plants with non-dehiscent pods cannot persist in nature, while plants with dehiscing pods cannot be harvested. This exerts a situation of disruptive selection forcing wild peas to remain wild, cultivated peas to remain cultivated, and products of rare crosses between them to join either of the two gene pools with respect to pod dehiscence. Another important adaptation of wild peas to their unstable habitats is seed dormancy, absent in cultivated peas (Weeden, 2007).

We have compiled a reliable collection of about 60 accessions of truly wild peas with dehiscing pods and reliable labels, which, together with a cultivated pea collection, allows to investigate patterns of the genus divergence. First we worked out a simple diagnostic system of three dimorphic molecular markers, $r b c L$, coxl and $S C A$, from the plastid, mitochondrial and nuclear genomes, respectively, allowing to classify overwhelming majority of peas into three major groups with 
respect to three most frequent allelic combinations of those markers. These combinations were denoted as A ( $r b c L$ with the restriction site for Hsp AI, coxl with the restriction site for Psi I, fast SCA electromorph), C (differing from A by the absence of the $P s i$ I recognition site in $\operatorname{coxl}$ ) and B (the mentioned restriction sites missing both from $r b c L$ and coxl, slow $S C A$ electromorph) (Kosterin and Bogdanova, 2008; Kosterin et al., 2010). From this point of view we attempted reconstruction of phylogeography of wild peas (Kosterin et al., 2010; Zaytseva et al., 2017). We made a phylogeny reconstruction based on the genes His5 and His7 of histone $\mathrm{H} 1$ subtypes 5 and 7 , of which the former appeared a good phylogenetic marker (Zaytseva et al., 2012; 2015). In the resulting trees, based on just two concatenated nuclear genes (Zaytseva et al., 2015), three main clades were resolved: (1) including only $P$. fulvum, with combination A; (2) with only wild representatives of $P$. sativum, with combinations A and C ('clade AC'), and (3) containing wild and cultivated accessions of $P$. sativum, with combination B ('clade B') (some peas with rare marker combination appearing in the two latter). The cultivated subspecies $P$. sativum subsp. sativum formed a branch inside the lineage B, while $P$. abyssinicum (with combination A) formed a small branch inside the lineage $\mathrm{AC}$, in accordance with previous phylogenetic studies in the genus (Ellis et al., 1998; Vershinin et al., 2003; Jing et al., 2010; Kreplak et al., 2019), that argues against its species rank (Weeden, 2018). At the same time, carriers of combinations $\mathrm{A}$ and $\mathrm{C}$ were interspersed in the 'lineage $\mathrm{AC}$ ', that is, the difference between combination $\mathrm{C}$ and $\mathrm{A}$ consisting in the absence/presence of a recognition site for the $P s i$ I endonuclease in the mitochondrial coxl gene did not look a phylogenetic landmark.

Since the mentioned evolutionary lineages were isolated on the basis of three markers, of which one was from the plastid genome and one from the mitochondrial genome, it was natural to conduct phylogenetic analyses based on the entire organellar genomes, which contain a great amount of phylogenetically valuable information (Van der Paer et al., 2017) and, unlike the nuclear sequences, have the advantage of avoiding meiotic recombination between parental genomes.

Earlier we undertook sequencing and phylogenetic analysis of the plastid genomes for 22 mostly wild pea accessions (Bogdanova et al., 2018). The reconstructed phylogeny in general corresponded to that obtained on the basis of nuclear histone $\mathrm{H} 1$ genes (Zaytseva et al. 2012; 2015) again showing 'lineages AC and B', but in addition revealed two unexpected basic divegrences. Accessions of $P$. fulvum clustered with two wild pea accessions classified as $P$. sativum subsp. elatius s.l., from Georgia and Turkey. The latter, an enigmatic wild pea accession P 013 from Tokat Province, is remarkable for exhibiting amphicarpy, thought to be confined to $P$. fulvum, that phenotypically proves relevance of its reconstructed phylogenetic position, suggesting its being a 'missing link' between $P$. sativum and $P$. fulvum representing an early branching of their common ancestor (Bogdanova et al., 2018). This accession also formed a basic branch on the tree based on a histone H1 gene, His5 (Zaytseva et al., 2012). The fact that one of diverse wild pea accessions from the Caucasus also belonged to the same branch in the plastid tree was puzzling. The other unexpected branch on the plastid genome tree, the first 
divergence of the main P. sativum clade, was formed by sole accession JI 1096, one of a series of wild pea accessions from the Athos Peninsula, Greece, which looked as typical wild peas of Southern Europe. Hence JI 1096 looked like carrying some cryptic ancient plastid lineage on the otherwise 'common' genetic background (Bogdanova et al., 2018).

In the plastid genome tree (Bogdanova et al., 2018), as well as on the histone H1 trees (Zaytseva et al., 2012; 2015), carriers of different alleles of the mitochondrial coxl gene did not cluster to each other. Thus it was interesting to reconstruct phylogeny based on the mitochondrial genomes. Until present, no mitochondrial genome of pea has been published. We undertook high throughput sequencing of both organellar genomes in a set of 38 pea accessions, 35 of which represent genuine wild peas, proved to have dehiscing pods. Each accession was represented by a progeny of a single plant randomly chosen from those provided by germpasm collections, or in some cases collected in nature. We assume that a single individual well represents a local wild pea population, since their populations are isolated, very small in number (tens to hundreds of plants) and area occupied (Abbo et al., 2008; 2013; Smýkal et al., 2018; Kosterin et al., 2020) and are characterised by scarce intra-population genetic diversity (Zaytseva et al., 2015; Smýkal et al., 2018).

We compared phylogenetic reconstructions on the basis of mitochondrial genomes and plastid genomes and revealed several principal discordances between them. This result suggests an important role of ancient hybridisation and nuclearplastid incompatibility in shaping microevolution of peas, and perhaps of many other plants.

\section{Materials and methods}

\subsection{Plant material}

This study is based on 38 pea accessions of mostly wild and some cultivated peas (Table 1) of broad geographical origin and representing a wide range of variation. They were obtained from Agricultural Research Service of the United States Department of Agriculture thanks to the courtesy of Clarice Coyne, from John Innes Centre thanks to the courtesy of Michael Ambrose, from Cornell University thanks to Norman Weeden, from Vavilov All-Union Institute of Plant Breeding, kindly provided by Petr Smykal, or collected from nature by ourselves. In each case, a single plant was chosen and its progeny was involved into analysis. 
Table 1. Pea accession studied (ordered by provenance from west to east) with accompanying information (in square brackets where reconstructed rather than provided by sources), their constitution of organellar genomes with respect to their main evolutionary branches (see 'Results') and Gene Bank accession number of corresponding DNA sequences.

\begin{tabular}{|c|c|c|c|c|c|c|}
\hline $\begin{array}{l}\text { accession } \\
\text { designation } \\
\text { adopted in } \\
\text { this paper }\end{array}$ & $\begin{array}{l}\text { other known } \\
\text { designations/ } \\
\text { taxonomic } \\
\text { attributions of } \\
\text { this accession }\end{array}$ & $\begin{array}{l}\text { origin; date of collection } \\
\text { (where relevant/available), } \\
\text { collector/originator; reference } \\
\text { (if published in a paper) }\end{array}$ & $\begin{array}{l}\text { lati- } \\
\text { tude } \\
(\mathrm{N})\end{array}$ & $\begin{array}{l}\text { longi- } \\
\text { tude } \\
\text { (E) }\end{array}$ & $\begin{array}{l}\text { organellar } \\
\text { constitution, } \\
\text { allele } \\
\text { combi- } \\
\text { nation } \\
\text { of three } \\
\text { markers } \\
\text { (where } \\
\text { available) }\end{array}$ & $\begin{array}{l}\text { ID numbers in } \\
\text { databases for } \\
\text { plastid genome, } \\
\text { mitochondrial } \\
\text { genome and } \\
\text { His5 gene } \\
\text { (sequences } \\
\text { obtained anew } \\
\text { underlined) }\end{array}$ \\
\hline \multicolumn{7}{|c|}{ Pisum fulvum, wild } \\
\hline WL 2140 & $\begin{array}{l}\text { WL 2029; } \\
\text { JI 224; } \\
\text { PI 560061 }\end{array}$ & Israel, Valley of the Cross. & {$[31.77]$} & {$[35.20]$} & P1 M1, A & $\begin{array}{l}\text { MG458702, } \\
\text { FR848865, } \\
\text { mitogenome ID } \\
\text { pending }\end{array}$ \\
\hline 706 & $\begin{array}{l}\text { JI } 3268, \\
\text { PI } 560065, \\
\text { L96 }\end{array}$ & $\begin{array}{l}\text { Israel, Ruhama, a coastal } \\
\text { plain, on calcareous } \\
\text { sandstone, in dwarf-shrub } \\
\text { formation (Ben-Ze'ev \& } \\
\text { Zohary, 1973) }\end{array}$ & [31.5] & {$[34.7]$} & P1 M1, A & $\begin{array}{l}\text { MG458703, } \\
\text { FR848856, } \\
\text { mitogenome ID } \\
\text { pending }\end{array}$ \\
\hline PI 343955 & $\begin{array}{l}\text { PIG 49, } \\
22645, \\
\text { G } 19532\end{array}$ & $\begin{array}{l}\text { Turkey, mountains above Ka } \\
\text { ( } 2 \text { km by road), arid limeston } \\
\text { E slope, } 60 \text { m a.s.l., Coll. Ma } \\
1969 \text { by H.S. Gentry. } \\
\text { (Heterogeneous for very } \\
\text { strong vs nil leaflet serration; } \\
\text { the non-serrate type analysed }\end{array}$ & $\begin{array}{l}\text { ş } \\
\text { le } \\
\end{array}$ & {$[29.7]$} & P1 M1 & pending \\
\hline \multicolumn{7}{|c|}{ Pisum abyssinicum, cultivated } \\
\hline VIR 2759 & $\begin{array}{l}\text { WL 1491, } \\
\text { WL } 2042\end{array}$ & Ethiopia & no data & $\begin{array}{l}\text { no } \\
\text { data }\end{array}$ & P4 M2, A & $\begin{array}{l}\text { MG859923, } \\
\text { FR848852, } \\
\text { mitogenome ID } \\
\text { pending }\end{array}$ \\
\hline WL 1446 & & no data & $-"$ - & -“- & $\mathrm{P} 4 \mathrm{M} 2, \mathrm{~A}$ & $\begin{array}{l}\text { FR848845, IDs } \\
\text { for organellar } \\
\text { genomes } \\
\text { pending }\end{array}$ \\
\hline \multicolumn{7}{|c|}{ Pisum sativum L. subsp. elatius (Bieb.) Aschers. et Graebn. s.1., wild } \\
\hline IG 64350 & & Algeria, Blida & {$[36.5]$} & {$[2.8]$} & P4 M1, A & $\begin{array}{l}\text { MG882488, } \\
\text { MH269702, } \\
\text { mitogenome ID } \\
\text { pending }\end{array}$ \\
\hline CE11 & $\begin{array}{l}\text { JI 3557, W6 } \\
\text { 56891, PE1 }\end{array}$ & $\begin{array}{l}\text { Portugal, Trás-os-Montes e } \\
\text { Alto Douro Province, } \\
\text { Bragança District, Vimioso } \\
\text { Municipality, } 1.4 \mathrm{~km} \mathrm{NE} \mathrm{of} \\
\text { Uva village, } 8.07 .2010 \text {, O. } \\
\text { Kosterin (Zaytseva et al., } \\
\text { 2015). }\end{array}$ & 41.50 & -6.48 & P4 M3, C & $\begin{array}{l}\text { MG882484, } \\
\text { LN812960, } \\
\text { mitogenome ID } \\
\text { pending }\end{array}$ \\
\hline JI 2724 & & Spain, Menorca, Mahon & [39.87] & {$[4.30]$} & $\mathrm{P} 4 \mathrm{M} 2, \mathrm{~A}$ & $\begin{array}{l}\text { FR848867, IDs } \\
\text { for organellar } \\
\text { genomes } \\
\text { pending }\end{array}$ \\
\hline
\end{tabular}


bioRxiv preprint doi: https://doi.org/10.1101/2020.05.19.104224; this version posted May 21, 2020. The copyright holder for this preprint (which was not certified by peer review) is the author/funder, who has granted bioRxiv a license to display the preprint in perpetuity. It is made available under aCC-BY-NC-ND 4.0 International license.

\begin{tabular}{|c|c|c|c|c|c|c|}
\hline 723 & $\begin{array}{l}\text { JI } 3271, \\
\text { PI } 560060, \\
\text { L106 }\end{array}$ & $\begin{array}{l}\text { Italy, Sardinia, Cagliari } \\
\text { env., in hedges (Ben-Ze'ev } \\
\& \text { Zohary; 1973). Perhaps a } \\
\text { hybrid with P. sativum } \\
\text { subsp. elatius (Zaytseva et } \\
\text { al., 2018) }\end{array}$ & [39.2] & [9.1] & $\mathrm{P} 4 \mathrm{M} 2, \mathrm{~A}$ & $\begin{array}{l}\text { FR848846, IDs } \\
\text { for organellar } \\
\text { genomes } \\
\text { pending }\end{array}$ \\
\hline PIS 2845 & & $\begin{array}{l}\text { Italy, Sicily, Palermo } \\
\text { [Prov.], Balze di Cugliace - } \\
\text { Palazzo Adriano }\end{array}$ & [37.7] & [13.4] & P4 M3, C & $\begin{array}{l}\text { MG833029, } \\
\text { MH269699, } \\
\text { mitogenome ID } \\
\text { pending }\end{array}$ \\
\hline PI 344537 & & $\begin{array}{l}\text { Italy, Sicily, Palermo } \\
\text { [Prov.], Bosco della } \\
\text { Ficuzza. Coll. by A. Di } \\
\text { Martino }\end{array}$ & [37.9] & [13.4] & P4 M4, C & $\begin{array}{l}\text { MG882489, } \\
\text { FR848890, } \\
\text { mitogenome ID } \\
\text { pending }\end{array}$ \\
\hline PIS 2853 & & $\begin{array}{l}\text { Hungary, Baranya, } \\
\text { [Siklósiközség, } \\
\text { Nagyharsány env.,] } \\
\text { Szársomlyó [Mt.]. }\end{array}$ & [35.85] & [18.41] & $\mathrm{P} 4 \mathrm{M} 3, \mathrm{C}$ & $\begin{array}{l}\text { MG882487, } \\
\text { MH269700, } \\
\text { mitogenome ID } \\
\text { pending }\end{array}$ \\
\hline JI 1091 & $\begin{array}{l}\text { PI 344005, } \\
\text { W6 8705, } \\
22611\end{array}$ & $\begin{array}{l}\text { Greece, Athos Peninsula, } \\
\text { Karyes, } 400 \text { m a.s.l., } \\
\text { among open secondary } \\
\text { shrubs, heavy ground litter, } \\
\text { upper edge of olive grove. } \\
\text { Coll. June } 1969 \text { by H.S. } \\
\text { Gentry }\end{array}$ & 40.25 & 24.33 & P4 M4, C & $\begin{array}{l}\text { MG859920, } \\
\text { FR848866, } \\
\text { mitogenome ID } \\
\text { pending }\end{array}$ \\
\hline JI 1096 & $\begin{array}{l}\text { PI } 344013, \\
\text { W6 8710, } \\
22735\end{array}$ & $\begin{array}{l}\text { Greece, Athos Peninsula, } \\
\text { above Karyes, } 450 \text { m a.s.l., } \\
\text { chestnut and oak woodland. } \\
\text { Coll. June } 1969 \text { by H.S. } \\
\text { Gentry }\end{array}$ & 40.25 & 24.33 & P3 M3, C & $\begin{array}{l}\text { MG859921, } \\
\text { FR848874, } \\
\text { mitogenome ID } \\
\text { pending }\end{array}$ \\
\hline W6 10925 & & $\begin{array}{l}\text { Bulgaria, } 30 \mathrm{~m} \text { from beach } \\
\text { at Albena, off sandy side of } \\
\text { trail, } 5 \mathrm{~m} \text { a.s.1.. Coll. } \\
\text { 28.06.1992 by R.M. Hanno } \\
\text { and W.J. Kaiser }\end{array}$ & [43.37] & [28.08] & P5 M4, B & pending \\
\hline PI 343974 & $\begin{array}{l}22632, \\
\text { G } 23875\end{array}$ & $\begin{array}{l}\text { Turkey, [Muğa Il], } 2 \mathrm{~km} \\
\text { SE of Selimiye } \\
\text { [(Marmaris)] on road to } \\
\text { Milas, field margin along } \\
\text { stream bank, in Rubus } \\
\text { thickets, } 70 \mathrm{~m} \text { a.s.l. Coll. } \\
\text { May } 1969 \text { by H.S. Gentry }\end{array}$ & [36.68] & [28.12] & P4 M2 & pending \\
\hline P 017 & $\begin{array}{l}\text { PI 560973, } \\
\text { W6 9813, } \\
270685-0105\end{array}$ & $\begin{array}{l}\text { Turkey, Mersin Il, } 19 \mathrm{~km} \\
\text { of road from Aydinchik to } \\
\text { Gulnar,790 m a.s.l. Coll. } \\
27.06 .1985 \text { by W.J. Kaiser, } \\
\text { F.J. Muehlbauer } \\
\text { (Muehlbauer et al., 1990) }\end{array}$ & [36.28] & [33.39] & P5 M4, B & $\begin{array}{l}\text { FR848843, IDs } \\
\text { for organellar } \\
\text { genomes } \\
\text { pending }\end{array}$ \\
\hline PI 343999 & 22699 & $\begin{array}{l}\text { Turkey, Mersin Il, on the } \\
\text { road } 6 \mathrm{~km} \text { N of Gülek, } \\
\text { scarce in a wheat field, } 120 \\
\text { m a.s.l. Coll. May } 1969 \text { by } \\
\text { H.S. Gentry }\end{array}$ & [37.30] & [34.77] & P4 M1 & $\begin{array}{l}\text { MT468418, IDs } \\
\text { for organellar } \\
\text { genomes } \\
\text { pending }\end{array}$ \\
\hline Pe 013 & $\begin{array}{l}190785- \\
0105, \\
\text { claimed to be } \\
\text { the same as } \\
\text { PI } 560969 \\
\text { and W6 } 9809 \\
\text { but these are } \\
\text { some } \\
\text { different } \\
\text { genotype, see } \\
\text { (Bogdanova } \\
\text { et al., 2018) }\end{array}$ & $\begin{array}{l}\text { Turkey, Tokat Province, } \\
\text { the left side of the road } \\
\text { from Sivas to Tokat about } \\
5 \mathrm{~km} \text { from Tokat, } 1 \mathrm{~km} \text { to } \\
\text { Geryaz village, a rocky } \\
\text { stony slope near water } \\
\text { canal, } 750 \mathrm{~m} \text { a.s.l. } \\
\text { (Muehlbauer et al., 1990; } \\
\text { see comments in } \\
\text { Bogdanova et al., 2018) }\end{array}$ & [40.26] & [36.55] & $\mathrm{P} 2 \mathrm{M} 2, \mathrm{~A}$ & $\begin{array}{l}\text { MK440218, } \\
\text { FR848882, } \\
\text { mitogenome ID } \\
\text { pending }\end{array}$ \\
\hline
\end{tabular}


bioRxiv preprint doi: https://doi.org/10.1101/2020.05.19.104224; this version posted May $21,2020$. The copyright holder for this preprint (which was not certified by peer review) is the author/funder, who has granted bioRxiv a license to display the preprint in perpetuity. It is made available under aCC-BY-NC-ND 4.0 International license.

\begin{tabular}{|c|c|c|c|c|c|c|}
\hline Pse 001 & $\begin{array}{l}010689- \\
0201 \\
\text { W6 } 1972\end{array}$ & $\begin{array}{l}\text { Turkey, Elazig Il, NW side } \\
\text { of Hazar Lake, near } \\
\text { cemetery, ca } 3 \mathrm{~km} \mathrm{~S} \mathrm{of} \mathrm{Firat} \\
\text { University Research } \\
\text { Station; on the road from } \\
\text { Elazig to Diyarbakyr, } 1270 \\
\text { m a.s.l. Coll. 01.06.1989 by } \\
\text { W.J. Kaiser, F.J. } \\
\text { Muehlbauer, C.R. Sperling. } \\
\text { (Muehlbauer et al., 1990) }\end{array}$ & 38.50 & 39.37 & P3 M4 & $\begin{array}{l}\frac{\text { MK440219, }}{\text { MT468417, ID }} \\
\text { for mitochon- } \\
\text { drial genome } \\
\text { pending }\end{array}$ \\
\hline P 015 & $\begin{array}{l}\text { PI 560971, } \\
\text { W6 9811, } \\
\text { 090785-03 }\end{array}$ & $\begin{array}{l}\text { Turkey, Diyarbakyr Il, on } \\
\text { road to Siverek, Karaçadag } \\
\text { (Karyarallari Park), } 42 \mathrm{~km} \\
\text { W of Diyarbakyr. Coll. } \\
\text { 09.07.1985 by W.J. Kaiser, } \\
\text { F.J. Muehlbauer } \\
\text { (Muehlbauer et al., 1990) }\end{array}$ & [37.9] & {$[39.7]$} & P5 M4, B & $\begin{array}{l}\text { FR848854, IDs } \\
\text { for organellar } \\
\text { genomes } \\
\text { pending }\end{array}$ \\
\hline Psh 004 & $\begin{array}{l}\text { W6 2044, } \\
\text { 070689-0202 }\end{array}$ & $\begin{array}{l}\text { Turkey, Mardin Il, } 8 \mathrm{~km} \\
\text { NE of Kiziltepe then } 7.7 \\
\text { km NW on road through } \\
\text { Kocalar Ortakoy village, } \\
770 \text { m a.s.l., infrequently in } \\
\text { terraces, rock fences, } \\
\text { ravine slopes on limestone } \\
\text { soil. Coll. 07.06.1989 by } \\
\text { W.J. Kaiser, F.J. } \\
\text { Muehlbauer (Muehlbauer } \\
\text { et al., 1990) }\end{array}$ & 37.30 & 40.63 & P5 M4 & $\begin{array}{l}\text { MK455838, IDs } \\
\text { for organellar } \\
\text { genomes } \\
\text { pending }\end{array}$ \\
\hline Psh 005 & $\begin{array}{l}\text { W6 2060, } \\
080689- \\
0403 ; P . \\
\text { sativum } \\
\text { subsp. elatius } \\
\text { var. pumilio }\end{array}$ & $\begin{array}{l}\text { Turkey, Mardin Il, } 10.7 \mathrm{~km} \\
\text { S of Midyat on the Midyat- } \\
\text { Gizre road. In grassy areas } \\
\text { of chickpea field margin; } \\
1050 \text { m a.s.l. Coll. } \\
08.06 .1989 \text { by W.J. Kaiser, } \\
\text { F.J. Muehlbauer, C.V. } \\
\text { Sperling (Muehlbauer et } \\
\text { al., 1990) }\end{array}$ & 37.37 & 41.42 & P5 M4 & pending \\
\hline JI 1794 & $\begin{array}{l}716, \\
\text { 'northern } \\
\text { humile' }\end{array}$ & $\begin{array}{l}\text { Golan Heights, ca. } 3 \mathrm{~km} \\
\text { NW of Quneitra, Tell Abu } \\
\text { Nida (Ben-Ze'ev \& Zohary; } \\
\text { 1973). }\end{array}$ & {$[33.1]$} & {$[35.8]$} & P5 M4, B & $\begin{array}{l}\text { HG966675, } \\
\text { FR846218, } \\
\text { mitogenome ID } \\
\text { pending }\end{array}$ \\
\hline 721 & $\begin{array}{l}\text { JI } 3262, \\
\text { PI } 560058, \\
\text { L104, } P . \\
\text { elatius }\end{array}$ & $\begin{array}{l}\text { Israel, Mt. Carmel, } 5 \text { km } \\
\text { NE of Zikhron Ya'akov, in } \\
\text { maquis (Ben-Ze'ev \& } \\
\text { Zohary, 1973). }\end{array}$ & [32.59] & {$[35.00]$} & $\mathrm{P} 4 \mathrm{M} 2, \mathrm{~A}$ & $\begin{array}{l}\text { HG966673, } \\
\text { FR848849, } \\
\text { mitogenome ID } \\
\text { pending }\end{array}$ \\
\hline 712 & $\begin{array}{l}\text { JI } 3273, \\
\text { PI } 560069, \\
\text { L100, } \\
\text { 'southern } \\
\text { humile' }\end{array}$ & $\begin{array}{l}\text { Israel, } 10 \mathrm{~km} \mathrm{~S} \text { of Be'er } \\
\text { Sheva; wadi bed with loess } \\
\text { deposit, as a weed in barley } \\
\text { (Ben-Ze'ev \& Zohary, } \\
1973 \text { ) }\end{array}$ & {$[31.15]$} & [34.80] & P4 M1, A & $\begin{array}{l}\text { HG966676, } \\
\text { FR848840, } \\
\text { mitogenome ID } \\
\text { pending }\end{array}$ \\
\hline JI 3233 & & Syria & no data & no data & P5 M4, B & $\begin{array}{l}\text { MG882485, } \\
\text { MH269701, } \\
\text { mitogenome ID } \\
\text { pending }\end{array}$ \\
\hline VIR 320 & & $\begin{array}{l}\text { probably a hybrid of a wild } \\
\text { pea from Palestine and the } \\
\text { cultivated pea (Bogdanova } \\
\text { et al., 2018) }\end{array}$ & - & - & P4 M1, A & $\begin{array}{l}\text { HG966672, } \\
\text { FR848838, } \\
\text { mitogenome ID } \\
\text { pending }\end{array}$ \\
\hline CE1 & $\begin{array}{l}\text { JI 2629, } \\
\text { W6 } 56882\end{array}$ & $\begin{array}{l}\text { USSR, Crimea, Simeiz, } \\
\text { open juniper forest on a } \\
\text { coastal slope. Coll. } \\
6.07 .1991 \text { by Y. Trusov, I. } \\
\text { Makunin and O. Kosterin }\end{array}$ & 44.40 & 33,98 & P5 M4, B & $\begin{array}{l}\text { MG859922, } \\
\text { FR848851, } \\
\text { mitogenome ID } \\
\text { pending }\end{array}$ \\
\hline
\end{tabular}


bioRxiv preprint doi: https://doi.org/10.1101/2020.05.19.104224; this version posted May 21, 2020. The copyright holder for this preprint (which was not certified by peer review) is the author/funder, who has granted bioRxiv a license to display the preprint in perpetuity. It is made available under aCC-BY-NC-ND 4.0 International license.

\begin{tabular}{|c|c|c|c|c|c|c|}
\hline CE3 & W6 56884 & $\begin{array}{l}\text { Russia, Krasnodarskiy } \\
\text { Kray, Anapa Municipality, } \\
1.5 \text { km ESE of Malyy } \\
\text { Utrish village,, } 47 \text { m a.s.1., } \\
\text { a dry glade in open oak- } \\
\text { juniper-pistachio stand on a } \\
\text { SW slope. Coll. } 22.07 .2017 \\
\text { by O.E. Kosterin, V.S. } \\
\text { Bogdanova }\end{array}$ & 44.7050 & 37.4750 & P5 M4 & $\begin{array}{l}\text { MK952764, IDs } \\
\text { for organellar } \\
\text { genomes } \\
\text { pending }\end{array}$ \\
\hline CE9 & W6 56889 & $\begin{array}{l}\text { Iran, Ostan-e Lorestan } \\
\text { Ostan, Shakhrestan-e } \\
\text { Aligudarz, Bakhsh-e } \\
\text { Besharat, } 700 \mathrm{~m} \mathrm{~N} \text { of the } \\
\text { centre of Kagelestan-e Bar } \\
\text { Aftab village, } 1841 \text { m a.s.l., } \\
\text { the Rudarb-e Aligudarz } \\
\text { River valley right slope } \\
\text { with open stand of Prunus } \\
\text { scoparia and grazed by } \\
\text { cattle. Coll. } 23.05 .2017 \text { by } \\
\text { coll. O. Kosterin (Kosterin } \\
\text { et al., 2020) }\end{array}$ & 33.0369 & 49.6564 & P5 M4 & $\begin{array}{l}\text { MK952766, IDs } \\
\text { for organellar } \\
\text { genomes } \\
\text { pending }\end{array}$ \\
\hline W6 26112 & G1001 & $\begin{array}{l}\text { Georgia, [Shida Kartli } \\
\text { Province], Ateni Sioni } \\
\text { Church, south facing slope, } \\
\text { basaltic area with many } \\
\text { stones and boulders and } \\
\text { some grass. Coll. 1.07.2004 } \\
\text { by F.J. Muehlbauer, M. } \\
\text { Akhalkatsi, W.J. Kaiser } \\
\end{array}$ & 41.904 & 44.094 & P5 M4 & pending \\
\hline W6 26109 & G0801 & $\begin{array}{l}\text { Georgia, [Kvemo Kartli } \\
\text { Region, Trialeti Range], } 20 \\
\text { km of Manglisi, } 7 \mathrm{~km} \mathrm{~N} \mathrm{of} \\
\text { Partsklisi, a roadside slope } \\
\text { with weeds and some } \\
\text { grasses, } 278 \text { m a.s.l. Coll. } \\
30.06 .2004 \text { by F.J. } \\
\text { Muehlbauer, M. } \\
\text { Akhalkatsi, W.J. Kaiser }\end{array}$ & 41.602 & 44.522 & P2 M1, A & $\begin{array}{l}\text { MG882486, } \\
\text { MH269698, } \\
\text { mitogenome ID } \\
\text { pending }\end{array}$ \\
\hline VIR 2998 & $\begin{array}{l}\text { P. elatius } \\
\text { subsp. } \\
\text { caspicum } \\
\text { Govorov } \\
\end{array}$ & $\begin{array}{l}\text { Georgia; received by VIR } \\
\text { from Riga Botanical } \\
\text { Garden; a subline from a } \\
\text { heterogeneous accession }\end{array}$ & no data & no data & P5 M4, B & $\begin{array}{l}\text { FR848886, IDs } \\
\text { for organellar } \\
\text { genomes } \\
\text { pending }\end{array}$ \\
\hline IG 140562 & & $\begin{array}{l}\text { Azerbaijan, Shamakhi } \\
\text { [District] }\end{array}$ & 40.69 & 48.64 & P5 M4 & $\begin{array}{l}\text { MT468420, IDs } \\
\text { for organellar } \\
\text { genomes } \\
\text { pending }\end{array}$ \\
\hline \multicolumn{7}{|c|}{ Pisum sativum subsp. sativum, cultivated } \\
\hline WL 1238 & & $\begin{array}{l}\text { testerline by H. Lamprecht } \\
\text { (Anonymus, 1984) }\end{array}$ & $\begin{array}{l}\text { not } \\
\text { appl. }\end{array}$ & $\begin{array}{l}\text { not } \\
\text { appl. }\end{array}$ & P5 M3, B & $\begin{array}{l}\text { HG966674, } \\
\text { FR848836, } \\
\text { mitogenome ID } \\
\text { pending }\end{array}$ \\
\hline WL 1072 & & $-"-$ & $-"-$ & $-"$ - & P5 M4, B & $\begin{array}{l}\text { MG917089, } \\
\text { MH269697, } \\
\text { mitogenome ID } \\
\text { pending }\end{array}$ \\
\hline Cameor & & cultivar & $-“-$ & $-“-$ & P5 M4 & pending \\
\hline \multicolumn{7}{|c|}{ Vavilovia formosa (outgroup) } \\
\hline- & & $\begin{array}{l}\text { Russia, North Osetia } \\
\text { (Shatskaya et al., 2019) } \\
\text { (organellar genomes analysec }\end{array}$ & $\begin{array}{l}\text { no } \\
\text { data }\end{array}$ & $\begin{array}{l}\text { no } \\
\text { data }\end{array}$ & not appl. & $\begin{array}{l}\text { MK604478, } \\
\text { MK48602 and } \\
\text { MK48603, }\end{array}$ \\
\hline- & & $\begin{array}{l}\text { Turkey (Zaytseva et al., } 2015 \\
\text { (His5 gene analysed) }\end{array}$ & $-"$ - & $-"-$ & $-“-$ & HG934385 \\
\hline
\end{tabular}




\subsection{Total and organellar DNA extraction, PCR amplification and DNA sequencing}

Genomic DNA was extracted using a protocol described in Bogdanova et al. (2012). Organellar DNA was extracted according to the protocol of plastid DNA extraction by Jansen et al. (2005) with modifications as described in Bogdanova et al. (2015). One step of the protocol, aimed to separate plastids from mitochondria, was omitted, namely, the centrifugation for $17 \mathrm{~min}$ at $4 \mathrm{C}$ at $20,000 \mathrm{~g}$ in a step gradient consisting of $6 \mathrm{ml} 60 \%$ suchrose overlayed with $20 \mathrm{ml}$ of $40 \%$ suchrose. By this, DNA of both organelles was isolated. This approach was similar to that of Siniauskaya et al. (2020).

PCR amplification and Sanger sequencing of the His5 gene were made at the SB RAS Genomics Core Facility as described in Bogdanova et al. (2018).

\subsection{Ion Torrent PGM sequencing and assembly of organellar genomes}

Ion Torrent PGM sequencing was performed at IC\&G Center of Genomic Investigations as described in Bogdanova et al. (2015).

To assemble mitochondrial genomes we used the same array of data which was used for the assembly of plastid genomes. It was possible since the read pool in about 10\% consisted of mitochondrial DNA (Bogdanova et al., 2015). First, the mitochondrial genome of the WL1238 accession was assembled. Assembly was made starting from a complement of contigs obtained in de novo assembly without reference sequence by MIRA4 (Chevreux et al., 1999). A contig consisting of mitochondrial DNA was selected by BLAST search (Altshul et al., 1990) at www.ncbi.nlm.nih.gov using mitochondrial DNA of Vicia faba L. (KC189947) as a query. Then the initial stretch of mitochondrial DNA was elongated by an overlapping contig which was searched with the Search function of the Tablet 1.13.07.31 assembly viewer (Milne et al., 2013). When more than one contig overlapped with a nascent mitochondrial assembly, the choice was made by chance. The elongation process was made in both directions until the forming large contig closed into a circle or a sigma-like structure. To procced with the assembly, the second starting mitochondrial DNA stretch was chosen on the basis of its homology with $V$. faba mitochondrial genome not yet included in the assembly. This was elongated in a similar way until it closed into a circle or merged with a circle already assembled. The latter was possible due to the contings refuted by the random choice when constructing the first circle. Then the third stretch of mitochondrial DNA not yet included into the assembly was chosen by homology with $V$. faba mitochondrion and the procedure was repeated. The process lasted until there remained regions of $V$. faba mitochondrial DNA homologous to pea sequences and not covered by the assembly constructed. In the case of WL1238 three large circles were obtained with the sizes of about 72, 125, $165 \mathrm{~kb}$, the latter including a stem-loop structure.

Overlaps of these three circles were identified using the blastn algorithm at blast.ncbi.nlm.nih.gov. Four overlaps of about $200 \mathrm{bp}$ were found (schematically 
presented in Fig. 1). Evidently, there are various manners to resolve the overlapping circular DNAs into a master circle since each join/repeat has two entrances and two exits that implies four possible configurations of the DNA pass, in a manner of the ' 8 ' figure or as two circles. This fact probably reflects the nature of plant mitochondrial DNA which exists as a set of interconverting sub-genomic molecules due to homologous recombination between repeated regions (Gualberto et al., 2014; Kozik et al., 2019). In fact, each of the alternative configurations was represented by some contigs of the starting set. The resulting assembly, however, should have included only two of four possible configurations. The length of overlaps was about $200 \mathrm{bp}$ that is comparable with the mean length of an IonTorrent read which is $188 \mathrm{bp}$. Therefore, to choose the best way of resolving the joins, using the mirabait utility of the MIRA package (Chevreux et al., 1999), we filtered the reads which crossed both boundaries of a join; the number of such reads was 4 to 10 per join. The DNA pass of individual reads was checked. In three cases it was represented by only two configurations that indicated the best way to resolve the joins. In the fourth case, of 10 reads that crossed both boundaries, 3 were of one type and 6 of another supporting the ' 8 ' configuration, and 1 of the third type, supporting the 'two circles' configuration. This join was resolved as to form configuration supported by the majority of reads. Totally, two of possible joins were resolved in a manner of the figure ' 8 ' and two - in a manner of nonoverlapping circles. The DNA pass in the resulting master circle is presented in Fig. 1 as dashed line.

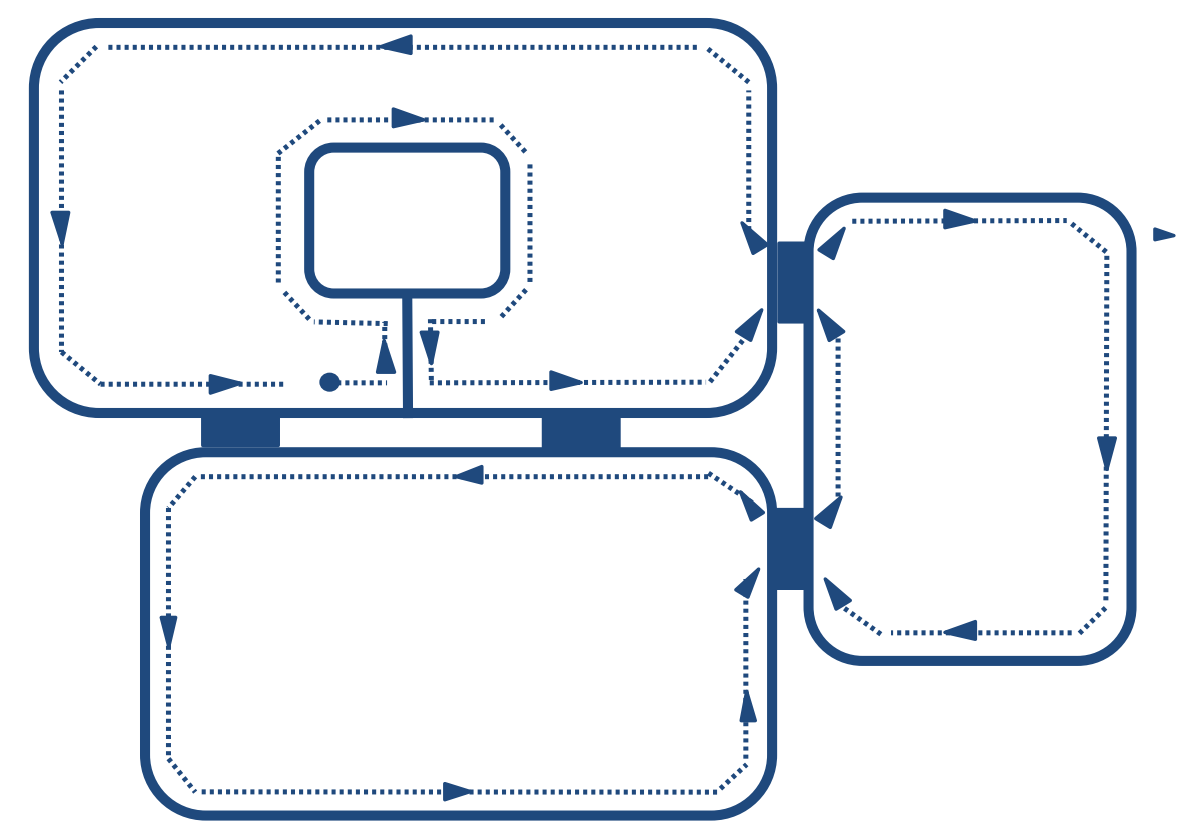

Figure 1. Schematic presentation of mitochondrial genome assembly of the accesssion WL1238. Solid lines represent assembled circular contigs, solid rectangles - overlapping DNA stretches, dashed line with arrowheads represents the DNA pass in the master molecule assembly. The solid circle is the starting point in the resulting assembly. 
The reconstructed mitogenome of WL1238 was then used as reference to map mitochondrial genomes of the rest accessions. However, in some pea lines, mitochondrial DNA could not be assembled on the backbone of that of WL1238 and presented obvious cases of rearrangements, as well as large deletions/insertions. In these cases, the entire assembling procedure was made $d e$ novo as described above.

Plastid genomes were assembled as described in Bogdanova et al. (2015; 2018) using the MIRA4 software (Chevreux et al., 1999).

\subsection{Alignment and evaluation of nucleotide variation of organellar genomes}

The assembled organellar genomes were aligned by ClustalW (Larkin, 2007) program incorporated into Mega 6 package (Tamura et al., 2013) and manually adjusted.

In a number of accessions, the reconstructed mitogenomes had large deletions, insertions, structural rearrangements as compared to the reference mitogenome of WL1238. To align them, the DNA sequence was broken into 5 to 13 parts which were then manually put in an order and orientation corresponding to the reference sequence.

The plastid and mitochondrial genomes were compared to that of WL1238 ( $P$. sativum subsp. sativum) and the differences registered, are summarized in Appendices A and B, respectively.

\subsection{Phylogenetic tree construction}

Bayesian MCMC analysis was performed with the use of BEAST 2.4.3. software (Drummond \& Rambaut, 2007). jModelTest 2.1.10 (Darriba et al., 2012; Guindon and Gascuel, 2003) was used to estimate substitution rates, proportion of invariant sites, Gamma shape parameter and to choose the GTR+I+G model. An uncorrelated lognormal relaxed clock model and Yule process of speciation were applied. One MCMC analysis was run for 100 million generations.

Computations were made at Computational Facility of the Siberian Supercomputer Center SB RAS and Computational Facility of Novosibirsk State University. Trees were visualized in FigTree 1.4.3 (http://tree.bio.ed.ac.uk/software/figtree/ by A.Rambaut).

The reconstructions were rooted with the same outgroup, Vavilovia formosa (Stev.) A. Fed. (Table 1), a perennial plant most related to peas (Pisum L.). Its plastid and mitochondrial genomes were earlier sequenced by Shatskaya et. al. (2019) and the His5 gene by Zaytseva et al. (2015). To root a reconstruction based on the mitochondrial genomes, that of Vicia faba (KC189947) was also used. 


\section{Results}

\subsection{Size and structure of pea mitochondrial genomes}

The lenght of the assembled mitogenomes varied in the range of 346,959$385,511 \mathrm{bp}$. According to their length, the assembled mitogenomes fell into three groups. The shortest mitogenomes, 346,959 and 354,692 bp belonged to the abyssinian pea accessions, WL 1446 and VIR 2759, respectively. The most abundant group of 28 accessions had mitogenomes of 363,029-363,928 bp, the third group of 7 accessions had longer mitogenomes $-379,890$ to 379,987 , and the accession 712 had the longest mitogenome of 385,511 bp due to an about $15 \mathrm{Kbp}$ repeat, however, in the latter case, assembly artifact is not excluded. The size differences were due to large insertions/deletions. In comparison with the mitogenome of WL1238 taken as reference, longer mitogenomes of the third group differed by about $32 \mathrm{~Kb}$ of inserted and about $17 \mathrm{~Kb}$ deleted DNA. The shortest mitogenome of the WL1446 abyssinian pea differed by about $17 \mathrm{~Kb}$ of deleted DNA, mitogenome of VIR2759 differed from that of WL 1238 by about $15 \mathrm{~Kb}$ deleted and about $6 \mathrm{~Kb}$ inserted DNA. These large insertions/deletions, however, concerned non-coding regions and did not change the gene content. The only exception was the above mentioned $15-\mathrm{Kb}$ repeat in 712 which contained three tRNA genes.

Apart from the size differences, the assembled mitogenomes differed by the gene order. Although the employed assembly algorithm admits ambiguities, possible variants of the resulting assemblies are compatible with the complements of the original reads. On the contrary, the revealed distinct structural types cannot be assembled from the given read set. Based on the criterion of compatibility with the read sets, six structural types of mitochondrial genomes were distinguished, which corresponded well to the above mentioned size groups. The most abundant 363-364 Kb group included two structural types which could be interconverted by two recombination events. Two other structural types were represented by two shorter $P$. abyssinicum mitogenomes, that of VIR 2759 arranged as one master circle and that of WL 1446 arranged as a sigma-like structure. The other two structural types were observed in the group of longer genomes, one in 7 accessions with mitogenomes of about $379 \mathrm{~Kb}$ and the other in the longest mitogenome of 712.

\subsection{Variability of pea mitochondrial genomes}

To estimte variability, each of the assembled mitochondrial genomes was compared to that of WL 1238 taken as reference and the observed differences were registered (Appendix B) which are referred to as mutations, including nucleotide substitutions, indels and small inversions (up to $10 \mathrm{bp}$ ). The number of different mutations was counted for each gene and intergenic region. The mean value of the 100 -fold number of different mutations in the mitochondrial genomes as comparted to that of WL 1238 (Appendix B) per length unit was $0.131 \pm 0.03$ for 
coding regions and $0.935 \pm 0.069$ for non-coding regions. In plastid genomes of the same set of accessions these values comprised $0.386 \pm 0.074$ for coding regions and $1.955 \pm 0.148$ for non-coding regions. The proportion of indels among all mutations was about $43 \%$ in mitochondrial genomes and about $25 \%$ in plastid genomes.

\subsection{Phylogenetic reconstructions based on updated set of plastid genomes and nuclear His5 gene}

In this study we made phylogenetic reconstruction by the Bayesian MCMC method (Fig. 2) based on an almost twice as large (38 vs 22) set of pea plastid genomes than in our previous study (Bogdanova et al., 2018). Expectedly, the major pattern remained the same.

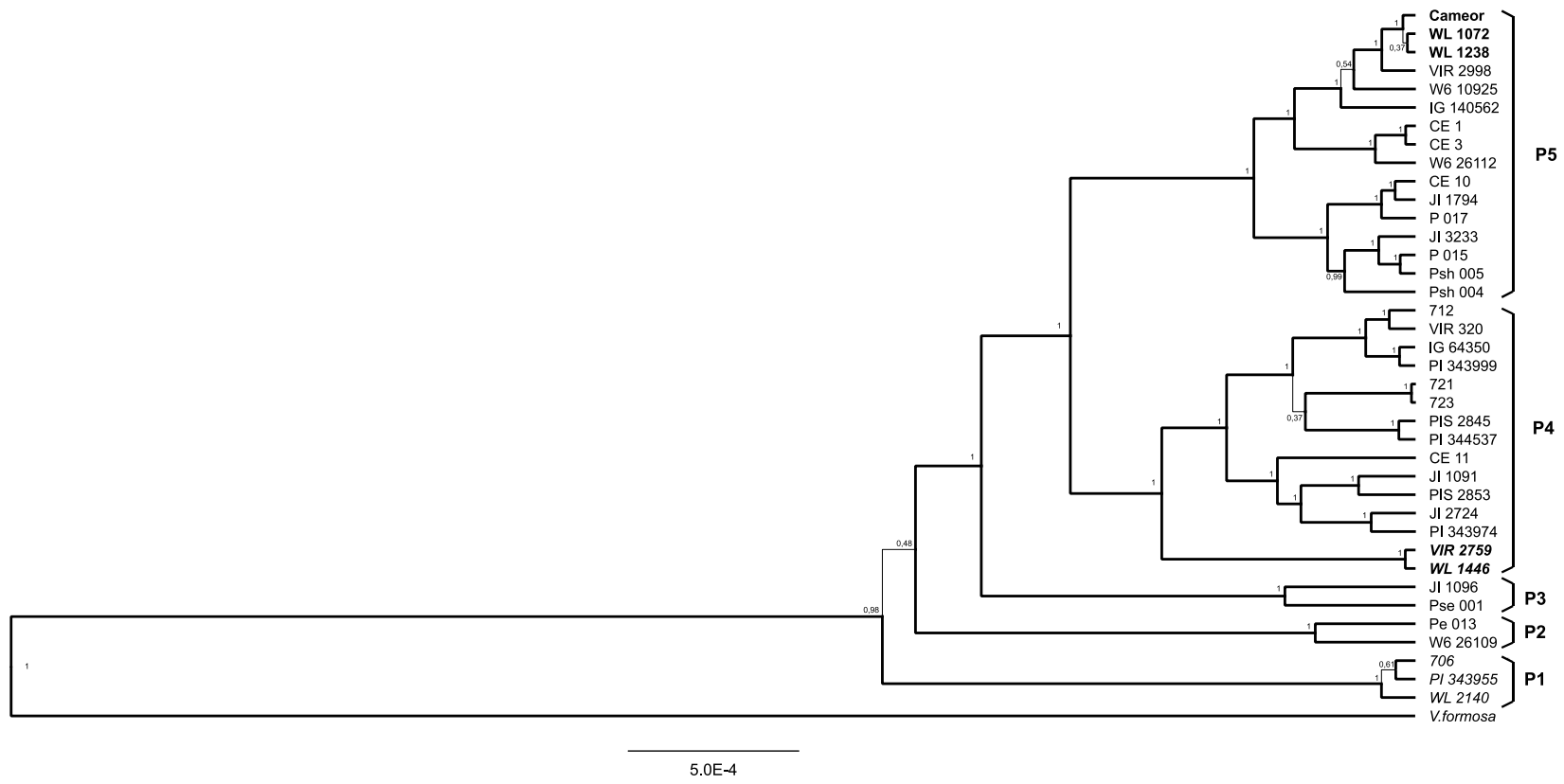

Figure 2. Bayesian reconstruction of phylogeny of the studied pea accessions on the basis of the plastid genomes. Posterior probabilities of the nodes are indicated. Branches corresponding to the nodes supported by the posterior probabilities higher than 0.5 are given as thick lines. Scale bar corresponds to the expected number of nucleotide substitutions per site. Main branches of the tree are designated as P1-P5. Accessions of Pisum fulvum are given in italics, of $P$. abyssinicum in bold italic, of the wild subspecies $P$. sativum subsp. elatius s.l. in regular Roman, of the cultivated subspecies $P$. sativum subsp. sativum in bold. Vavilovia formosa serves as outgroup.

For the purpose of comparison with other phylogenetic reconstructions, here we introduce designations of the main revealed branches, being an ordinal number preceded with the letter 'P' (for 'plastid') (Fig 2). 
The most ancient diverged branch P1 contains all the three involved accessions of $P$. fulvum and is opposed to the rest of the tree formed by representatives of $P$. sativum.

The next diverged branch $\mathrm{P} 2$ includes wild pea ( $P$. sativum subsp. elatius s.1.) accessions Pe 013 (Turkey) and W6 26109 (Georgia) and is an ancient plastid lineage "ascending to a 'missing link' between $P$. fulvum and $P$. sativum" revelaled eariler (Bogdanova et al., 2018). Its position on the tree is not well resolved, so that we may speak of three main clades of pea plastid genomes of uncertain mutual phylogenetic relationship, P1, P2 and the main $P$. sativum clade. The latter consists of three main branches.

The earliest branch P3 consists of two wild pea ( $P$. sativum subsp. elatius s.1.) accessions, JI 1096 from Greece and Pse 001 from Turkey. This branch was unexpectedly revealed in our earlier study being represented by the only accession JI 1096 (Bogdanova et al., 2018), here this branch has gained additional support by the second pea accession.

The large branch P4 includes diverse wild pea ( $P$. sativum subsp. elatius s.1.) accessions and corresponds to the 'lineage $\mathrm{AC}$ ' in our earlier terminology (Zaytseva et al., 2015; Bogdanova et al., 2018). The earliest divergence inside this branch is formed by the accessions (VIR 2759 and WL 1446) of cultivated $P$. abyssinicum.

The third branch P5, also very large, includes accessions lacking Hsp AI recognition site in the $r b c L$ allele (marker combination $\mathrm{B}$ ) and corresponds to the 'lineage B'. Most of them are wild peas, $P$. sativum subsp. elatius s.1.. It further branches to form a subbranch of seven accessions with about $3.5-\mathrm{Kb}$ inversion in the plastid genome (Palmer et al., 1985; Bogdanova et al., 2015) and a subbranch of nine accessions without such inversion, including cultivated peas. The three involved representatives of the common cultivated subspecies $P$. sativum subsp. sativum (Cameor, WL 1238 and WL 1072) are tightly clustered inside the latter subbranch. They form a larger cluster together with three P. sativum subsp. elatius accessions from Georgia (VIR 2998), Bulgaria (W6 10925) and Azerbaijan (IG 140562), which are wild peas yet sharing with cultivated peas the specific deletion in the trnH-psbA intergenic spacer (Zaytseva et al., 2017). Indeed, the plastid genomes of these three accessions are closely related to those of the cultivated peas, but they are not interspersed with them on the tree and occupy positions outside the 'cultivated cluster'.

The phylogenetic tree based on the updated set of sequences of the nuclear His5 gene has been reconstructed (Fig. 3). Its topology is in general similar to that of the tree based on the complete plastid genomes (Fig. 2) but is expectedly less resolved. Like in our earlier reconstruction (Bogdanova et al., 2018), four main clades are resolved: (i) of P. fulvum; (ii) of accession Pe 013; (iii) 'lineage AC' and (iv) 'lineage B'.

The differences from the plastid topology concern positions of two accessions. First, accession W6 26109 (Georgia) in the nuclear gene tree is found inside the 'lineage $\mathrm{AC}$ ' while in the plastid tree it is clustered with Pe 013 to form 
the ancient plastid lineage P2. The corresponding ancient lineage is also detected in the His 5 tree but it is represented solely by Pe 013 .

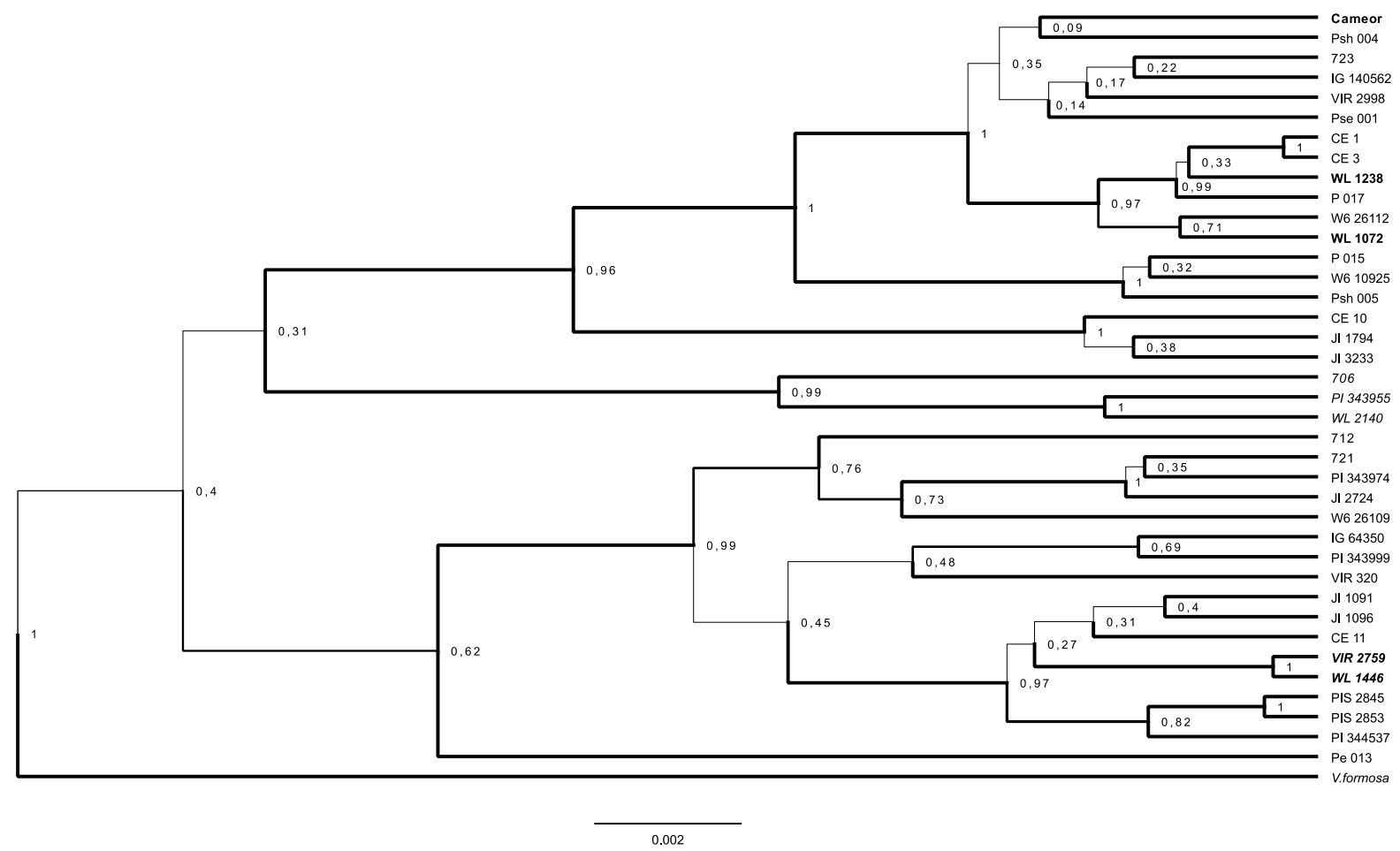

Figure 3. Bayesian reconstruction of phylogeny of the studied pea accessions on the basis of the nuclear His5 gene. Vavilovia formosa serves as outgroup. Designation of taxonomic attribution as in Fig. 2.

Second, accession 723 with combination A appeared inside 'lineage B'. This case is explainable since this accession, from Sardinia, although classified as 'Pisum elatius' by Ben-Ze'ev and Zohary (1973), has non-dehiscing pods and obviously is a result of hybridistion of wild and cultivated peas, as mentioned in Table 1.

\subsection{Phylogenetic reconstructions based on mitochondrial genomes}

The phylogenetic tree reconstructed by the Bayesian MCMC method from sequences of the mitochondrial genomes (Fig. 4) differed from the above considered trees drastically. Its six main unusual features were as follows:

(i) It contains three main clades of unresolved phylogenetic relationship, one of them represented by $V$. formosa, assumed to be the outgroup, and two others by peas, that is, the genus Pisum appears on this tree subdivided into two clades of the same rank as the genus Vavilovia.

(ii) The species P. fulvum is not opposed to P. sativum. One of the above mentioned principal Pisum clades includes P. fulvum and some representatives of 
$P$. sativum subsp. elatius s.l. of the lineage AC, the P. fulvum branch being immersed inside this clade. The other clade embraces the rest of $P$. sativum, wild and cultivated, and the accessions of $P$. abyssinicum.

(iii) The mitochondrial genomes of the accessions forming the ancient branch P2 in the plastid tree (Fig. 2), nominated to be a 'missing link' between $P$. fulvum and $P$. sativum, have no unusual characteristics. In the mitochondrial tree (Fig. 4) they are interspersed with representatives of the lineage AC.

(iv) Accessions of 'lineage AC' and 'lineage B' do not form monophyletic clades in the mitochondrial tree, while do so in the plastidic and His5 trees.

(v) There is a well resolved cluster of accessions with mitochondrial genomes lacking the $P s i$ I restriction site in the coxl gene, that is separating carriers of the combinations $\mathrm{B}$ and $\mathrm{C}$ from carriers of the ancestral combination $\mathrm{A}$ possessing the $P$ si I recognitions site.

(vi) While two of the three representatives of the common cultivated subspecies $P$. sativum subsp. sativum are tightly clustered, the third, WL 1238 , is found in another big cluster.

To distinguish the main branches on the phylogenetic trees based on the mitochondrial genomes (Fig. 4) we use designations starting with the letter ' $M$ ' ('mitochondria').

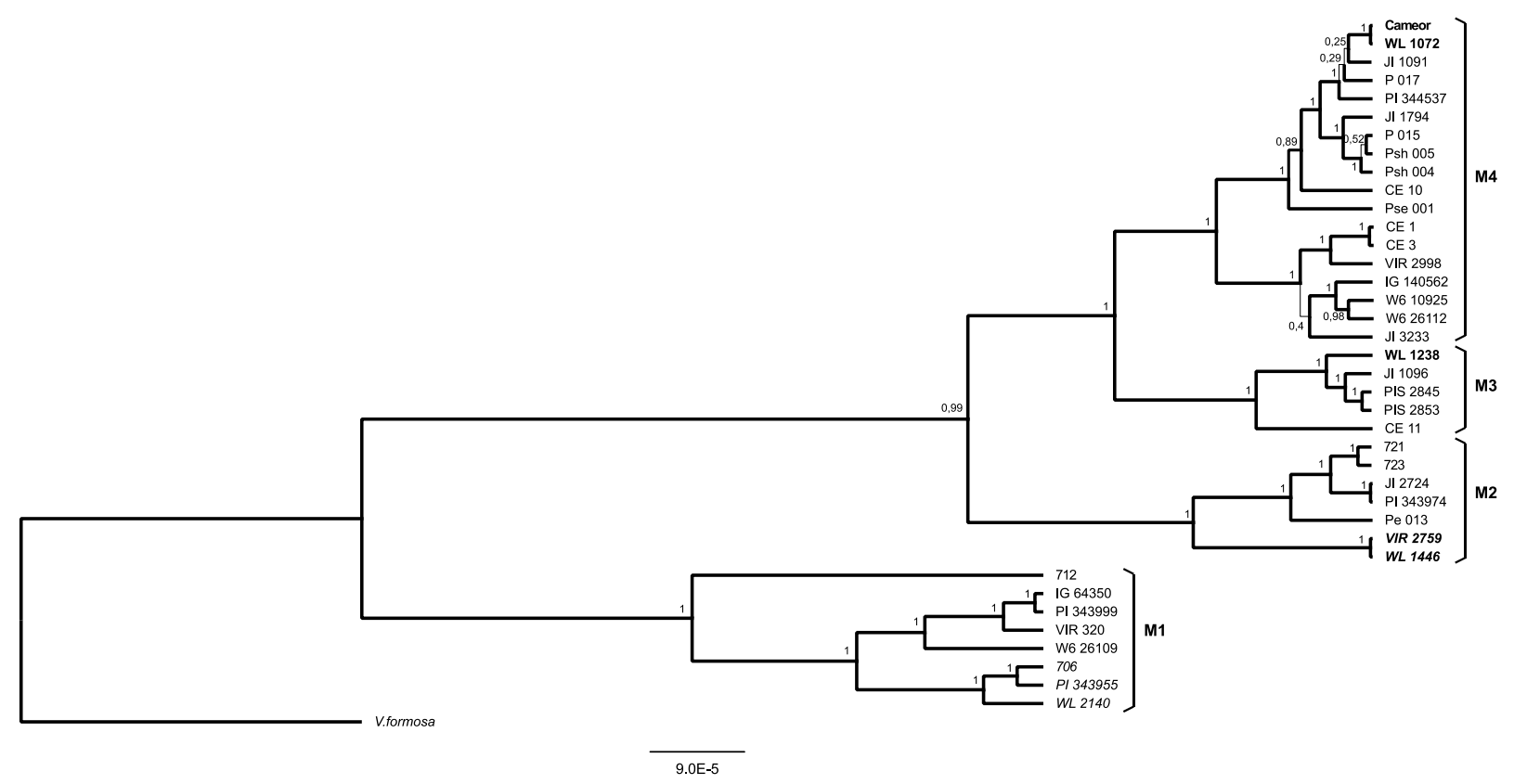

Figure 4. Bayesian reconstruction of phylogeny of the studied pea accessions on the basis of the mitochondrial genomes. Vavilovia formosa serves as outgroup. Main branches of the tree are designated as M1-M4. Designation of taxonomic attribution as in Fig. 2. 
The branch M1 includes all the three accessions of $P$. fulvum and five representatives of $P$. sativum subsp. elatius s.1. with marker combination A, from Algeria, Israel, Turkey and Georgia. Among them we find VIR 320 and 712 known to have plastids incompatible with nuclear genome of cultivated pea (Bogdanova et al., 2015), and W6 26109 - a Georgian accession from the ancient plastid lineage P2 (Bogdanova et al., 2018).

The branch M2 embraces accessions of $P$. sativum subsp. elatius s.1. (including Pe 013 from the ancient plastidic lineage P2) and the two accessions of $P$. abyssinicum, all with marker combination A.

The branch M3 includes four accessions of $P$. sativum subsp. elatius s.l. from Southern Europe with combination C and the testerline WL 1238 representing the cultivated subspecies.

The branch M4 includes the rest $P$. sativum subsp. elatius s.l. with combinations $\mathrm{B}$ and $\mathrm{C}$ and two representatives of the cultivated subspecies $P$. sativum subsp. sativum (Cameor and WL 1072).

\section{Discussion}

\subsection{Variation of pea mitogenomes}

It is well known that plant mitochondrial genomes exist as several structural isoforms (circular, linear or branched) permanently undergoing rearrangements at their repeated segments (Gualberto et al., 2014; Kozik et al., 2019). The here assembled mitogenomes represent isoforms, where possible, consisting of one master circle,. A structural type consisting of two master circles was revealed for the mitogenome of a close pea relative V. formosa (Shatskaya et al., 2019), while that in the genus Silene L. is represented by up to 128 circular 'chromosomes' (Sloan et al., 2012). A substantial structural variation in mitochondrial genomes was found e.g. in the genus Gossypium L. (cotton) (Chen et al., 2017) and family Oleaceae (Van de Paer et al., 2017). The enhanced rearrangement processes in the mitochondrial genomes as compared to the plastid genomes is the general trend in plants (Smith and Keeling, 2015). Existence in peas of six different structural types of mitogenomes is hence not surprising.

Of the six revealed structural types of mitochondrial genomes, one type embraced all accesssions of the lineages B and C (those lacking Psi I recognitionn site in the coxl gene), while mitogenomes of the lineage A were more structurally variable and possessed one of the rest five structural types revealed. Two of the structural types were confined to the M1 clade and three - to the M2 clade. For the purpose of alignment non-collinear mitogenomes were manually cut and the fragments then put in the order and orientation corresponding to that of WL 1238 . The number of pieces into which a given mitogenome should be cut to form a collinear reconstruction can serve as a measure of rearrangement events. This number was estimated as five for mitogenomes of the M2 clade, except for two abyssinian peas, which were separated by ten (VIR 2759) and 12 (WL 1446) 
rearrangements. Mitogenomes of the M1 clade differed from that of WL 1238 by 13 rearrangements except for 712 which differed by 10 rearrangements. Notably, the mitogenome structural types differed in the two accessions representing the same taxon $P$. abyssinicum which is rather uniform morphologically but variable karyologically (Kosterin, 2017).

Chen et al. (2017) reported that in spite of a very high rate in rearrangements of the mitochondrial genome in cotton, the rate of their molecular evolution in terms of nucleotide substitutions was only ca $1 / 6$ of that of the plastid genomes. The similar difference can be noted comparing the here made reconstructions for plastid (Fig. 2) and mitochondrial (Fig. 4) genomes. The given scale bars, although of the same physical size, correspond to $9 \times 10^{-5}$ nucleotide substitution per site for the mitochondrial tree and $5 \times 10^{-4}$ for the plastid tree, the former being ca $1 / 5$ of the latter and is very close to the estimate by Chen et al. (2017). Our estimates of the number of different nucleotide substitutions per length unit (including coding and non-coding regions) provided $3.17 \pm 0.37 \times 10^{-3}$ for mitochondrial genomes and $8.49 \pm 0.67 \times 10^{-3}$ for plastid genomes.

\subsection{Discordant evolution of oranelles in peas}

The phylogenetic reconstruction based on the mitochondrial genomes exhibits multiple discordances from that based the plastid genomes, as illustrated in Fig. 5. The most remarkable feature is that in the mitochondrial tree P. fulvum is no more the first branch of the genus but is clustered with five representatives of $P$. sativum subsp. elatius. Accessions Pe 013 and W6 26109 do not form any 'ancient lineage' as in the plastid genome tree. Accessions lacking the Hsp AI restriction site in the plastid $r b c L$ gene form a monophyletic clade in the plastid tree and the accessions lacking the $P s i$ I restriction site in the mitochondrial coxl gene form a monophyletic clade in the mitochondrial tree, but not vice versa. The last but not least, three representatives of the cultivated subspecies $P$. sativum subsp. sativum lost monophyly in the mitochondrial genome tree. These obvious discordances can only be interpreted through multiple hybridisation events between divergent pea lines which took place in the past and resulted in discordant inheritance of plastids and mitochondria. Signs of reticulate evolution in the genus Pisum were earlier traced, with the use of the Structure software, in phylogeny of a set of nuclear genes by Jing et al. (2007). Now we get its unequivocal evidence from the organellar phylogenies.

Spontaneous hybridisation of wild peas is not surprising. Although pea is often considered to be a selfer, it has conspicuous flowers and occasional crosspollination by bees does occur even in cultivated peas, especially in traditional local landraces from southern regions (Loening, 1984), since the pistil retains some ovules not yet fertilised with the own pollen when flower opens (Bogdanova and Berdnikov, 2000). Population genetic studies by Smýkal et al. (2018) evaluated the level of cross-pollination in wild peas in SE Turkey as 10-53\%. It is geographical isolation of wild peas as well as topographical isolation of their tiny populations from each other, rather than biological inability of crossing, which reduces 
probability of hybridisation, yet it did occur many times in the course of Pisum evolution (Jing et al., 2007; this paper).

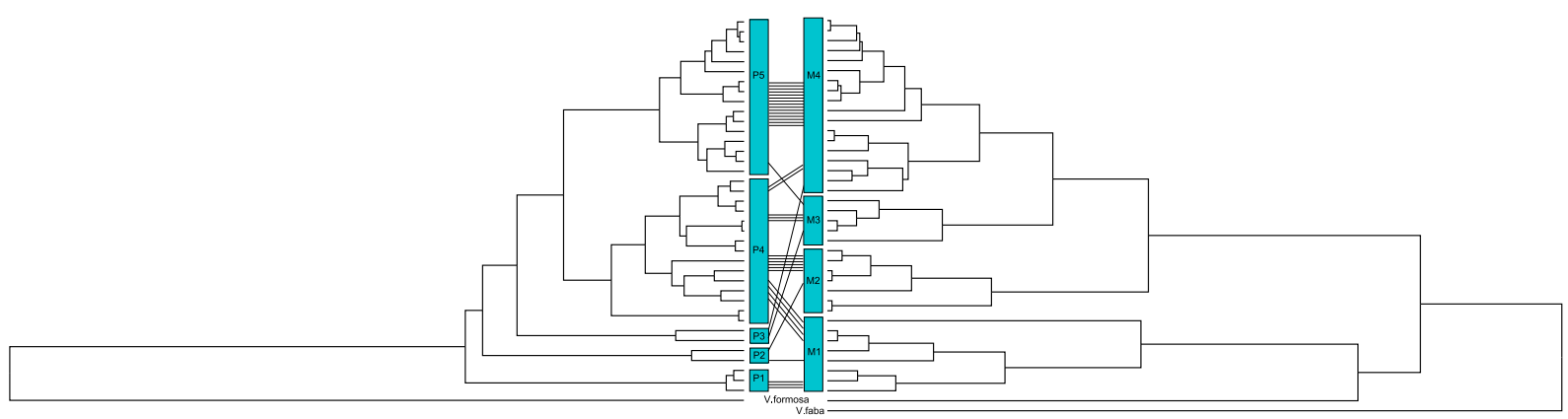

Figure 5. Comparison of phylogenetic trees reconstructed on the basis of plastid (left) and mitochondrial (right) genomes. Designations of main tree branches correspond to those of Fig. 2 and Fig. 4.

In contrast to the substantial discordance of the phylogenies based on mitochondrial and plastid genomes in peas revealed in this study, the similar comparison in the family Oleaceae showed unequivocal concordance in their topologies (Van der Paer et al., 2017).

The nuclear genomes should contain more sophisticated signatures of the hybridisation events which occurred during Pisum evolution, and SNP analysis, already attempted for peas (Smýkal et al., 2017; Kreplak et al., 2019), can shed light on them. However, the organellar genomes have an advantage of being free of meiotic recombination and hence are good landmark of evolutionary pathways.

\subsection{Position of Vavilovia}

In the reconstructed mitochondrial genome tree (Fig. 4), one of the pea branches is disposed very close to Vavilovia while the rest of peas reside on a long 'stem'. This is in contrast to the phylogenetic tree based on the plastid genomes where the entire genus Pisum crowns a long 'stem' sprouting after divergence from the common ancestor with Vavilovia (Fig. 2). This could be interpreted in terms of an accelerated evolution of mitochondrial genomes in one particular evolutionary lineage leading to the last common ancestor of the 'extended' branch. However, it would difficult to suppose any biological reason for this. More likely Vavilovia is not too appropriate outgroup for phylogenetic reconstruction based on the mitochondrial genome. 


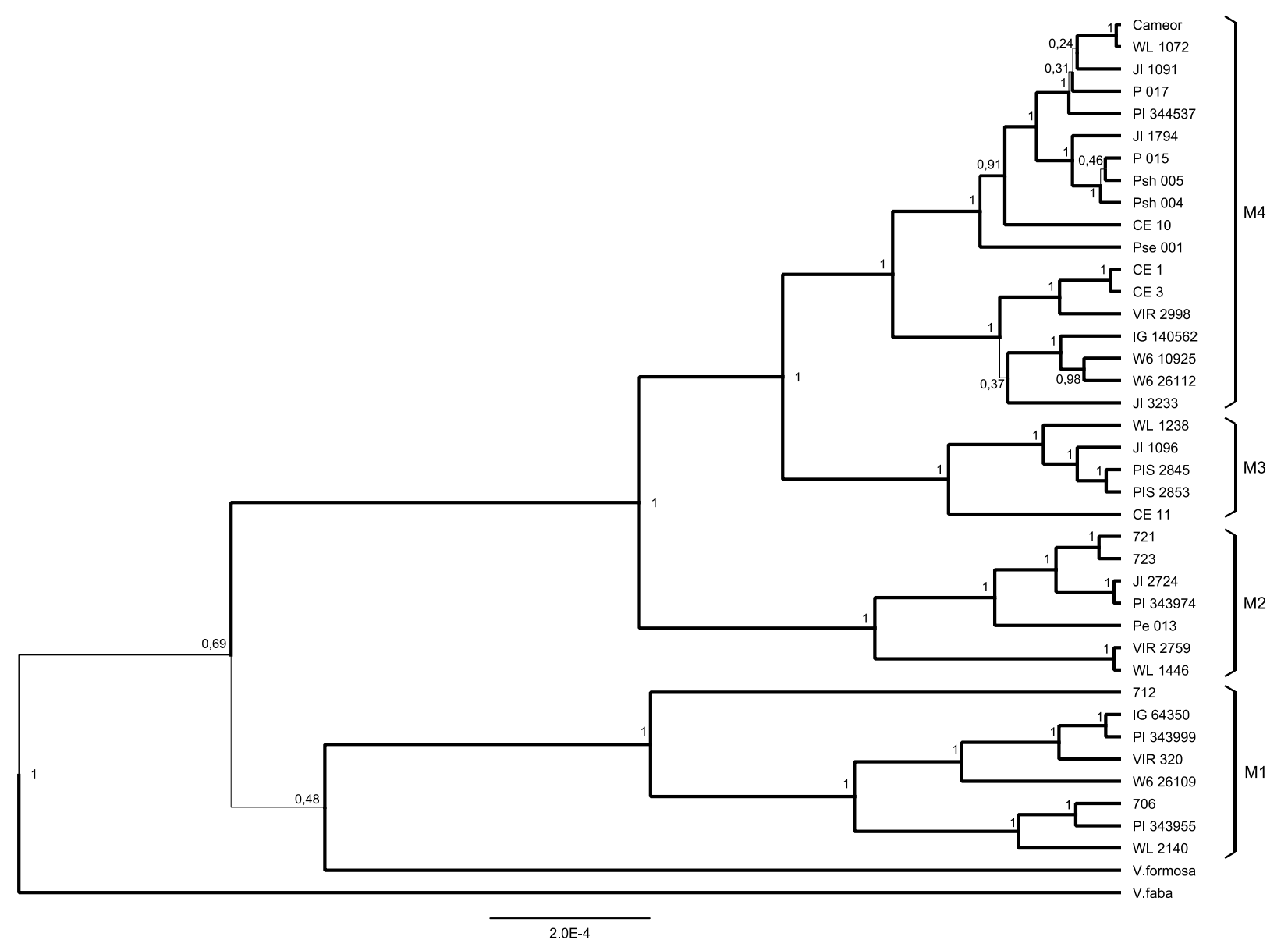

Figure 6. Bayesian reconstruction of phylogeny of the studied pea accessions, Vavilovia formosa and Vicia faba, on the basis of the mitochondrial genomes. Designations as in Fig. 4.

Vavilovia is traditionally considered a genus most close to Pisum, yet it differs from peas by perennial life cycle and a non-climbing habitus, being a low plant specialised to highland screes in the Caucasus and Anterior Asia (Vishnyakova, 2020). It looked the most fit outgroup for phylogenetic reconstruction in peas; for this purpose we obtained the sequences of plastid and mitochondrial genomes of Vavilovia formosa (Shatskaya et al., 2019). It served a good outgroup in reconstructing phylogeny of peas based on histone $\mathrm{H} 1$ genes (Zaytseva et al., 2015; this paper, Fig. 3) and the plastid genomes (Fig. 2), but, as noted above, offered a distorted tree when used for the mitochondrial genome reconstruction (Fig. 4). Addition to the analysis of the mitochondrial genome of a much more remote pea relative Vicia faba resulted in a remarkable tree (Fig. 6), in which Vavilovia clusters rather tightly with the pea mitochondrial branch M1. This can be interpreted as an ancient introgression of mitochondria from the ancestor of Vavilovia to the ancestors of peas united in the branch M1, or vice versa. Remarkably, the present-day Vavilovia and Pisum are too different plants inhabiting too different habitats to hybridise. Since it is Vavilovia which look highly specialised ecologically and morphologically in the entire tribe Fabea, it can 
be supposed that its ancestor had acquired pea mitochondria still before that specialisation took place and it still resembled peas in its habitus and life strategy.

\subsection{Organellar constitution and the number of past hybridisation events}

Earlier we introduced a system of combinations (A, B, C) of three molecular markers from the three cellular genomes to denote certain presumed lineages of pea evolution (Kosterin and Bogdanova, 2008; Kosterin et al.. 2010; Zaytseva et al., 2017). In view of the here presented new insight in phylogeny of the plastid and mitochondrial genomes, this system becomes insufficiently informative. For instance, it does not reflect belonging to some 'ancient lineages'. To facilitate discussion below we classify peas with respect to constitution of their organellar genomes as attributed to their main evolutionary branches with were denoted in sections 3.3 and 3.4. For instance, accession Pe 013 has constitution P2 M2, accession W6 26109 - P2 M1, accession 712 - P3 M1, cultivar Cameor - P5 M4, and so on. This organellar genomic constitution is indicated in Table 1. Correspondence of the genomic constitutions to the previously adopted marker combinations $\mathrm{A}-\mathrm{C}$ is shown in Table 2 .

Table 2. Correspondence of the genomic constitutions in the sense of this paper to combinations A, B, C of alleles of three molecular markers $r b c L, c o x l$ and $S C A$ from different cellular genomes according to Kosterin and Bogdanova (2008) and Kosterin et al. (2010)/

\begin{tabular}{|c|c|c|}
\hline combination & $\begin{array}{l}\text { organellar genomic } \\
\text { constitution }\end{array}$ & taxon (accessions) \\
\hline \multirow[t]{5}{*}{ A } & P1 M1 & P. fulvum (WL 2140, 706, PI 343955) \\
\hline & P2 M1 & P. sativum subsp. elatius (W6 26109) \\
\hline & P2 M2 & P. sativum subsp. elatius $(\mathrm{Pe} 013)$ \\
\hline & P4 M1 & $\begin{array}{l}\text { P. sativum subsp. elatius (VIR 320, 712, IG 64350, } \\
\text { PI 343999) }\end{array}$ \\
\hline & P4 M2 & $\begin{array}{l}\text { P. sativum subsp. elatius }(721,723, \text { JI } 2724 \text {, } \\
\text { PI } 343974, \text { Pe } 013 \text { ), } \\
\text { P. abyssinicum (WL 1446, VIR 2759) }\end{array}$ \\
\hline \multirow[t]{4}{*}{$\mathrm{C}$} & P3 M3 & P. sativum subsp. elatius (JI 1906) \\
\hline & P3 M4 & P. sativum subsp. elatius (Pse 001) \\
\hline & P4 M3 & $\begin{array}{l}\text { P. sativum subsp. elatius (CE 11, PIS 2845, } \\
\text { PIS 2853) }\end{array}$ \\
\hline & P4 M4 & P. sativum subsp. elatius (JI 1091, PI 344537) \\
\hline \multirow[t]{2}{*}{ B } & P5 M3 & P. sativum subsp. sativum (WL 1238) \\
\hline & P5 M4 & $\begin{array}{l}\text { P. sativum subsp. elatius (CE 3, CE 1, W6 10925, } \\
\text { W6 26112, JI 3233, VIR 2998, P 017, Psh 004, } \\
\text { Psh 005, CE 10, P 015, IG 140562, JI 1794) } \\
\text { P. sativum subsp. sativum (WL 1072, Cameor) }\end{array}$ \\
\hline
\end{tabular}

Note: Combination D, differing from combination B by the allele of the nuclear gene $S C A$, was found in some pea accessions with traces of hybridisation during reproduction but not in accessions of genuine wild peas. Accession PI 344537 (Sicily) has combination C and was earlier classified as having combination D (Zaytseva et al., 2017) due to a technical error (adopted from Kosterin and Bogdanova, 2008). 
Each case in the above mentioned constitutions where the same plastid branch is combined with more than one mitochondrial branch should be considered as evidence of an independent hybridisation event in the past. We can indicate six such cases: P2 with M1 or M2, P3 with M3 or M4, P4 with M1, M2, M3 or M4, P5 with M3 and M5. This is the lower estimate of the number of hybridisation events with discordant organellar inheritance in the evolution of Pisum. There could be more such events resulting in combinations of plastids and mitochondria of different sub-branches of their main evolutionary branches.

\subsection{Role of nuclear-cytoplasmic incompatibility in shaping organellar phylogeny}

The plant phenotype is mostly a product of its tens of thousands nuclear genes. We sequenced only one of them, His5, encoding a minor H1 histone subtype and not involved into the genetic program for morphogenesis.

Nevertheless, the phylogenetic tree reconstructed on the basis of the nucleotide sequence of this gene (Fig. 3) mostly agrees with expectations from the point of view of morphology and taxonomy; that is evolution of a single gene chosen for its high variability (Zaytseva et al., 2012) appears to have been in line with the mainstream pea evolution, more or less reflected in its taxonomy. The principal topology of the phylogenetic trees reconstructed by Kreplak et al. (2019: Fig. 6) on the basis of 2 thousand nuclear SNP is the same as in our tree based on a single nuclear gene (Fig. 3): the first branch of $P$. fulvum and further bifurcation into a branch with a part of accessions of $P$. sativum ssp. elatius s.l. (including ' $P$. humile') plus $P$. abyssinicum and a branch with the rest of $P$. sativum subsp. elatius plus $P$. sativum subsp. sativum. Unfortunately the analysis by Kreplak et al. (2019) included only seven accessions of $P$. sativum ssp. elatius s.l. (with only one of them, 721, in common with our analysis), although this inclusive subspecies embraces most of the species' diversity.

The tree reconstructed on the basis of the plastid genomes has two remarkable discordances with taxonomy and the nuclear gene tree, while the mitochondrial tree looks randomly reshuffled as compared to both of them. This evidences for occasional hybridisation to have taken place in the course of pea evolution, which generated new combinations of nuclear genes and organellar genomes. Two circumstances are important:

(i) the plastid and mitochondrial genomes had been discordantly inherited by the hybrids, that would be impossible with strict maternal inheritance of the organelles and,

(ii) the plastids were more often inherited concordantly with the sequenced nuclear gene, as well as unknown nuclear genes controlling the external phenotype, while inheritance of the mitochondria was more often discordant.

These facts can be explained through phenomena discovered by our team in remote pea crosses. Biparental and even paternal inheritance of plastids does occur in peas in the situation of nuclear-plastid conflict (Bogdanova and Kosterin 2006; Bogdanova, 2007; Bogdanova et al.; 2014; Kosterin and Bogdanova 2015) resulting from incompatibility of the plastid-encoded subunit of the plastidic 
heteromeric acetyl-coA carboxylase with one or two its subunits encoded in the nucleus (Bogdanova et al., 2009, 2012; 2015). Milder forms of this conflict appeared widespread in remote crosses involving different wild peas (Bogdanova et al., 2014), to make some combinations of certain plastids and some nuclear genes unviable or, more often, to result in complete or partial loss of fertility. It is noteworthy that the conflict can be overcome by occasional paternal plastid inheritance, so that the presence of paternal plastids in some plant sectors restores their normal phenotype (Bogdanova and Kosterin, 2006; Bogdanova, 2007). In evolutionary terms this means that not any combination of plastids with certain nuclear genes is allowed to be inherited by descendants of occasional spontaneous hybrids, that is, plastid inheritance is to some extent controlled by the nucleus.

At the same time, neither a conflict between the nucleus and mitochondria nor biparental or paternal inheritance of the latter was so far found in peas (Bogdanova, 2007). This means that the type of mitochondria inherited by descendants of a hybrid is determined only by the direction of the cross and is invariably maternal, and mitochondrial evolutionary lineages were not controlled by the nucleus. In some sense the mitochondrial tree shows the history of crosses between diverged peas in the course of the Pisum evolution.

As discussed above, comparison of the phylogenetic trees reconstructed from the plastid and mitochondrial genomes suggested independent cases of hybridisation between divergent evolutionary lineages to take place in the Pisum evolutionary history. They result in a number of organellar constitutions enumerated above, which, in our earlier system, are manifested in the marker combinations A, B and C. It is remarkable that certain constitutions, e.g. P5 M1 or P5 M2 (which would not fit these combinations) seem not to occur in wild peas. Earlier Kosterin and Bogdanova (2008) reported four pea accessions (of 89 studied) with unusual combinations of cellular genomes. Two of them, VIR 320* and WL 2123 were highly heterogeneous accessions represented by many genotypes with 'wild' and 'cultivated' traits found in different combinations and obviously represented segregated progeny of occasional crosses of wild and cultivated peas during reproduction. Accessions P 008 (Turkey) and L 90 (without provenance) were received as wild peas but appeared to have non-dehiscing pods hence the material we tested did not represent genuine wild peas.

We may conclude that in wild pea evolution, natural hybridisation of some peas with marker combinations $A$ and $B$ resulted in peas with plastids from the former and mitochondria from the latter but not vice versa. Since mitochondria are maternally inherited in peas, those with combination $\mathrm{C}$ most probably resulted from cases when peas with combination B were spontaneously cross-pollinated with those with combination A. Potential nuclear-plastid incompatibilities occurring in such crosses could have been alleviated by paternal plastid inheritance. 


\subsection{Phylogeographic implications}

All phylogenetic reconstructions obtained in this and our earlier (Zaytseva et al;, 2012; 2015) studies revealed a robust monophyletic branch embracing wild and cultivated accessions earlier recognised as 'lineage B' marked by the loss of certain restriction sites in the plastid $r b c L$ and mitochondrial coxl gene, earlier chosen to conventionally classify wild pea genetic diversity (Kosterin, Bogdanova, 2008; Kosterin et al., 2010). As follows from the here presented phylogenetic reconstructions based on the plastid and mitochondrial genomes, each of these two losses obviously occurred once in evolution, $H s p$ AI site in the plastidic $r b c L$ was lost at the origins of the plastid branch P5 (Fig. 2) and the Psi I site in mitochondrial coxl was lost during evolution of 'stem' leading to mitochondrial branches M4+M3 (Fig. 4).

Earlier Kosterin et al. (2010) supposed that peas with combination C represented a transitory stage of evolution leading to the 'lineage B', when the mitochondrial coxl already had lost the restriction site while the plastid $r b c L$ not yet, and that the difference between combinations $\mathrm{C}$ and $\mathrm{B}$ concerned the latter mutation only. In such a scenario, all phylogenetic reconstructions would show a monophyletic branch composed of accessions with combination $\mathrm{C}$ and the inner monophyletic branch of 'lineage B'. The revealed pattern is nothing like this and carriers of combination $\mathrm{C}$ do not represent a monophyletic group in any reconstructed tree. In the plastid tree (Fig. 2), the carriers of combination A (with mitochondria of the branches M1 and M2) and C (with mitochondria of the branches M3 and M4) are interspersed in the branch $\mathrm{P} 4$ without phylogenetic regularity. Also in the mitochondrial tree (Fig. 4), the carriers of combination B (with plastids of the branch P5) and C (with plastids of the branches P3 and P4) are interspersed without phylogenetic regularity in the branches M3 and M4.

This finding disproves the phylogeographic scenario proposed by us earlier (Kosterin et al., 2010), implying the evolution from carriers of the ancestral combination A of south-eastern Mediterranean to 'lineage B' inhabiting southeastern Mediterranean and Maghreb through 'intermediate peas' with combination $\mathrm{C}$ inhabiting Southern Europe. The phylogenetic patterns observed can only be interpreted if to assume that 'combination C', embracing four different organellar constitutions (Table 2), had not occurred via a loss of Psi I restriction site from the coxl gene in some representative of the lineage A, but originated from not less than four independent hybridisation events between the representatives of the plastid branches P3 and P4 and the mitochondrial branches M3 and M4.

An important inference from the above is that most of Southern Europe, from Sicily to Hungary and from Portugal to Greece, is inhabited by wild peas (with combination C) of hybrid origin. There we found the organellar constitutions P3 M3 (JI 1096, Greece), P4 M3 (3 accessions, from Portugal, Hungary and Sicily) and P4 M4 (JI 1091, Greece, and PI 344537, Sicily). Curiously, the constitutions P3 M3 and P4 M4 were found in the same series of wild peas collected by Howard Scott Gentry in 1969 at the Karyes Town on the Athos Peninsula, Greece, and constitutions P4 M3 and P4 M4 occur in the two accessions from Sicily. 
These presumable hybridisations could take place when wild $P$. sativum started to expand to Europe from the eastern Mediterranean from where the genus Pisum had originated. As a result of not less than three such events, the hybrid descendants got the allowed organellar constitution (manifested as marker combination C; one more hybrid organellar constitution corresponding to combination C, P3 M4, was not found in Europe). It should be stressed that they occurred between wild peas and long ago, without participation of cultivated peas (P. sativum subsp. sativum), since the mitochondrial genome of these European wild peas with combination $\mathrm{C}$ do not contain markers of the cultivated pea lineage, e.g. the 7-bp deletion in the trnH-psbA spacer (Zaytseva et al., 2017).

Wild peas of ancient hybrid origin with the organellar constitution P3 M4, are also found in Turkey (Pse 001).

The 'lineage B' (constitution P5 M4) can be supposed to originate in the Caucasus and Asia Minor, which it currently inhabits (Kosterin et al., 2010; Zaytseva et al., 2017). At present, wild representatives of $P$. sativum carrying plastids and mitochondria from different evolutionary clades, including their hybrid combination P4 M4 (combination C), grow side by side in Turkey, Israel and the Caucasus (Kosterin et al., 2008; Zaytseva et al., 2017; this study).

The accession WL 1238 is assumed to belong to the cultivated subspecies $P$. sativum subsp. sativum, yet it was found to possess an unexpected and unusual organellar constitution P5 M3 and hence falls out of 'lineage B' (althouth has the marker combination B). In should be noticed that this is a testerline created by Hebert Lamprecht as a multiple hybrid. We failed to trace in its available history (Anonymus, 1984) the source of M3 mitochondria which could be wild pea from Southern Europe, but have to suppose that such ancestor should have existed.

\subsection{Phylogeny and phenotype}

Accessions involved into our analysis of wild representatives of $P$. sativum, conventionally denoted as $P$. sativum subsp. elatius in a broad sense, were grown in greenhouse and demonstrated a great diversity with respect to external characters. Many of them possess remarkable and even unique characters. They could motivate erection of a number of taxa below the species rank but fortunately escaped attention of taxonomic botanists. For example, most leaves of Psh 004 (a low pea from E Turkey) are impairipinnate, composed of 3 to 5 leaflets, with the terminal tendril domain replaced with an apical leaflet. Accession PI 343999 (a low pea with strongly dentate leaflets from S Turkey) has a thick, fleshy pod walls (phenotype n), which was hitherto found among wild peas only in P. fulvum and was one of its diagnostic characters; at the same time the pods bear neoplastic pustules (phenotype Np) never occurring in P. fulvum. Accessions 712 and IG 64350 (low peas with dentate leaflets from S Israel and Algeria, respectively) are characterised by numerous purple dots on pod walls. Young plants of accession P 017 (a medium-tall accession from S Turkey) demonstrate transitory, lasting for 2-3 days, deep purple-violet anthocyanin hue of the foliage of the first 2-3 nodes, while mature plants bear some neoplastic pustules (phenotype $\mathrm{Np}$ ) on the stem, 
while normally they appear (in the greenhouse conditions) only on the pod walls. Accession Pse 001 (a tall pea from E Turkey) has a curious warm, carmine-red hue of its large, well pigmented flowers. Accession PI 343974 from SW Turkey is exceptionally tall and has very long pods. Some obviously unrelated accessions of distant provenance have extremely short, almost reduced peduncles, e.g. CE 11 (NE Portugal), JI 1091, JI 1096 (Greece), JI 3233 (Syria); based on this character the latter accession was attributed to $P$. sativum subsp. elatius var. brevipedunculata Davis thought to occur in Turkey and Cyprus (Davis. 1969). Iranian accessions CE 9 and CE 10 are characterised by extremely fast seed germination (like $P$. abyssinicum). Neither of these morphological peculiarities finds any reflection in the phylogenies reconstructed, as their carriers did not form distinct, early evolutionary branches. At the same time, an unusual character, amphycarpy, was found earlier in one (Pe 013) of the two accessions of the basal evolutionary branch $\mathrm{P} 2$ in the phylogenetic tree reconstructed from the plastid genomes (Bogdanova et al., 2018).

\section{Declaration of conflict of interest: none}

\section{Acknowledgements}

Funding: This work is supported by Russian State Scientific project № 03242019-0039-C-01 at the Institute of Cytology \& Genetics SB RAS, Novosibirsk and the project № 19-04-00162 of the Russian Fund for Fundamental Research. We thank Clarice Coyne, Michael Ambrose, Norman Weeden and Petr Smykal for providing valuable wild pea germplasm.

High-throughput sequencing was performed at IC\&G Center of Genomic Investigations, Sanger sequencing was performed at the SB RAS Genomics Core Facility, genome assembly and phylogenetic reconstruction were carried out with the use of Computational Facility of the Siberian Supercomputer Center SB RAS and Computational Facility of Novosibirsk State University. Plants were grown in the greenhouse of the SB RAS Artificial Plant Growing Facility.

\section{Appendix A. Supplementary material}

Differences registered in the sequenced plastid genomes as compared to that of accession WL1238 (Pisum sativum subsp. sativum)

\section{Appendix B. Supplementary material}

Differences registered in the sequenced mitochondrial genomes as compared to that of accession WL1238 (Pisum sativum subsp. sativum) 


\section{References}

Abbo, S., Zesak, I., Schwartz, E., Lev-Yadun, S., Gopher, A. 2008. Experimental harvesting of wild peas in Israel: implications for the origins of Near East farming. Journal of Archaeological Science 35: 922-929. https://doi.org/10.1016/j.jas.2007.06.016.

Abbo, S., Lev-Yadun, S., Heun, M. Gopher, A. 2013. On the 'lost crops' of the neolithic Near East. Journal of Experimental Botany 64: 815-822. https://doi.org/10.1093/jxb/ers373.

Altschul S.F., Gish W., Miller W., Myers E.W., Lipman D.J. 1990. Basic local alignment search tool. Journal of Molecular Biology. 215: 403-410. https://doi.org/10.1016/S0022-2836(05)80360-2

Ambrose, M.J., Ellis, T.H.N. 2008. Ballistic seed dispersal and associated seed shadow in wild Pisum germplasm. Pisum Genetics. 40, 5-10.

Anonymus. 1984. The Pisum-Genebank. Listings of Weibullsholm Collection. Nordic Gene Bank, Weibullsholm Plant Breeding Institute, p. 1-345.

Ben-Ze'ev, N., Zohary, D. 1973. Species relationship in the genus Pisum L. Israel J. Bot. 22, 73-91.

Bogdanova, V.S. 2007. Inheritance of organelle DNA markers in a pea cross associated with nuclear-cytoplasmic incompatibility. Theor. Appl. Genet. 114, 333-339. https://doi.org/10.1007/s00122-006-0436-6

Bogdanova, V.S., Berdnikov, V.A. 2000. A study of potential ability for crosspollination in pea originating from different parts of the world. Pisum Genetics. 32, 16-17.

Bogdanova, V.S., Galieva, E.R., Kosterin, O.E. 2009. Genetic analysis of nuclearcytoplasmic incompatibility in pea associated with cytoplasm of an accession of wild subspecies Pisum sativum subsp. elatius (Bieb.) Schmahl. Theor. Appl. Genet. 118, 801-809. https://doi.org/10.1007/s00122-008-0940-y

Bogdanova, V.S., Galieva, E.R., Yadrikhinskiy, A.K., Kosterin, O.E. 2012.

Inheritance and genetic mapping of two nuclear genes involved in nuclearcytoplasmic incompatibility in peas (Pisum sativum L.). Theor. Appl. Genet. 124, 1503-1512. https://doi.org/10.1007/s00122-012-1804-Z

Bogdanova, V.S., Mglinets, A.V., Shatskaya, N.V., Kosterin, O.E., Solovyev, V.I.,

Vasiliev, G.V. 2018. Cryptic divergences in the genus Pisum L. (peas), as revealed by phylogenetic analysis of plastid genomes. Mol. Phyl. Evol. 129, 280-290. https://doi.org/10.1016/j.ympev.2018.09.002

Bogdanova, V.S., Kosterin, O.E. 2006. A case of anomalous inheritance of chloroplasts in crosses of the garden pea with participation of one of the wild forms. Doklady Akademii Nauk. 406, 256-259 (in Russian).

Bogdanova, V.S., Kosterin, O.E., Yadrikhinskiy, A.K. 2014. Wild peas vary in their cross-compatibility with cultivated pea (Pisum sativum subsp. sativum L.) depending on alleles of a nuclear-cytoplasmic incompatibility locus. Theor. Appl. Genet. 127, 1163-1172. https://doi.org/10.1007/s00122-014-2288-9 Bogdanova, V.S., Zaytseva, O.O., Mglinets, A.V., Shatskaya, N.V., Kosterin, O.E., Vasiliev, G.V. 2015 Nuclear-cytoplasmic conflict in pea (Pisum sativum 
L.) is associated with nuclear and plastidic candidate genes encoding Acetyl-

CoA carboxylase subunits. PLoS ONE. 10 (3), e0119835.

https://doi.org/10.1371/journal.pone.0119835.

Chen, Z., Nie, H., Wang, Y., Pei H., Li, S., Zhang, L., Hua, J. 2017. Rapid evolutionary divergence of diploid and allotetraploid Gossypium mitochondrial genomes. BMC Genomics 18: 876 http://doi.org/10.1186/s12864-017-4282-5.

Chevreux, B., Wetter, T., Suhai, S. 1999. Genome sequence assembly using trace signals and additional sequence information. Computer Science and Biology: Proceedings of the German Conference on Bioinformatics (GCB). 99, 45-56.

Coulot, P., Rabaute, P. 2016. Monographie de Leguminosae de France. Tome 4. Tribus des Fabeae, des Cicereae et des Genisteae. Bulletin de la Société Botanique du Centre-Ouest. 46, 1-902.

Coulot, P., Rabaute, P. 2017. Deuxièmes compléments à la Monographie des Leguminosae de France. Le Monde des Plantes 516:11-35.

Darriba, D., Taboada, G.L., Doallo, R., Posada, D. 2012. jModelTest 2: more models, new heuristics and parallel computing. Nature Methods. 9 (8), 772. https://doi.org/10.1038/nmeth.2109

Davis, H. 1969. Materials for a flora of Turkey: XIX. Legumiosae: Vicieae. Notes of Royal Botanical Garden of Edinbourgh 29 (3): 311-320.

Drummond, A.J., Rambaut, A. 2007. BEAST: Bayesian evolutionary analysis by sampling trees. BMC Evol. Biol. 7, 1. https://doi.org/10.1186/1471-2148-7-214 Ellis, T.H.N., Poyser, S.J., Knox, M.R., Vershinin, A.V., Ambrose, M.J. 1998. Polymorphism of insertion sites of Tyl-copia class retrotransposons and its use for linkage and diversity analysis in pea. Mol. General Genet. 260, 9-19.

Gualberto, J.M., Mileshina, D., Wallet, C., Niazi, A.K., Weber-Lotfi, F., Dietrich, A. 2014. The plant mitochondrial genome: dynamics and maintenance. Biochimie 100: 107-120. https://doi.org/ 10.1016/j.biochi.2013.09.016.

Guindon, S., Gascuel, O. 2003. A simple, fast and accurate method to estimate large phylogenies by maximum-likelihood. Systematic Biology. 52, 696-704. https://doi.org/10.1080/10635150390235520

Jansen, R.K., Raubeson, L.A., Boore, J.L., dePamphilis, C.W., Chumley, T.W., Haberle, R.C., Wyman, S.K., Alverson, A.J., Peery, R., Herman, S.J., Fourcade, H.M., Kuehl, J.V., McNeal, J.R., Leebens-Mack, J., Cui, L. 2005. Methods for obtaining and analyzing whole chloroplast genome sequences. Methods Enzymol. 395, 348-384. https://doi.org/10.1016/S00766879(05)95020-9

Jing, R.C., Knox, M.R., Lee, J.M., Vershinin, A.V., Ambrose, M., Ellis, T.H.N., Flavell, A.J. 2005. Insertional polymorphism and antiquity of PDR1 retrotransposon insertions in Pisum species. Genetics. 171, 741-752. https://doi.org/10.1534/genetics.105.045112

Jing, R., R. Johnson, A. Seres, G. Kiss, M. J. Ambrose, Knox, R., Ellis, T.H.N., Flawell, A.J. 2007. Gene-based sequence diversity analysis of wild pea (Pisum). Genetics. 177, 2263-2275. https://doi.org/10.1534/genetics.107.081323 
Jing, R., Vershinin, A., Grzebota, J., Shaw, P., Smýkal, P., Marshall, D., Ambrose, M.J., Ellis, T.H.N., Flavell, A.J. 2010. The genetic diversity and evolution of field pea (Pisum) studied by high throughput retrotransposon based insertion polymorphism (RBIP) marker analysis. BMC Evolutionary Biology. 10, 44. https://doi.org/10.1186/1471-2148-10-44

Kosterin, O.E. 2016. Prospects of the use of wild relatives for pea breeding. Russian Journal of Genetics: Applied Research. 6 (3), 233-243. https://doi.org/10.1134/S2079059716030047

Kosterin, O.E. 2017. Abyssinian pea (Lathyrus schaeferi Kosterin nom. nov. pro Pisum abyssinicum A. Br.) is a problematic taxon. Vavilovskii Zhurnal Genetiki i Selektsii = Vavilov Journal of Genetics and Breeding. 1 (2), 158169. https://doi.org/10.18699/VJ17.234

Kosterin, O.E., Bogdanova, V.S. 2008. Relationship of wild and cultivated forms of Pisum L. as inferred from an analysis of three markers, of the plastid, mitochondrial and nuclear genomes. Genet. Res. Crop. Evol. 55, 735-755. https://doi.org/10.1007/s10722-007-9281-y

Kosterin, O.E., Bogdanova, V.S. 2015. Reciprocal compatibility within the genus Pisum L. as studied in F1 hybrids: 1. Crosses involving P. sativum L. subsp. sativum. Genet. Resour. Crop Evol. 62 (5), 691-709. https://doi.org/10.1007/s10722-014-0189-z

Kosterin, O.E., Bogdanova, V.S., Mglinets, A.V. 2020. Wild pea (Pisum sativum L. subsp. elatius Aschers. et Graebn. s. 1.) at the periphery of its range: Zagros Mountains. Vavilovskii Zhurnl Genetiki i Selektsii=Vavilov Journal of Genetics and Breeding 24 (1): 60-68. https://doi.org/10.18699/VJ20.596

Kosterin, O.E., Zaytseva, O.O., Bogdanova, V.S., Ambrose, M. 2010. New data on three molecular markers from different cellular genomes in Mediterranean accessions reveal new insights into phylogeography of Pisum sativum L. subsp. elatuis (Beib.) Schmahl. Genet. Resour. Crop Evol.. 57, 733-739. https://doi.org/10.1007/s10722-009-9511-6

Kozik, A., Rowan, B.A., Lavelle, D., Berke, L., Schranz, E., Michelmore, R.W., Christensen, A.C.. 2019. The alternative reality of plant mitochondrial DNA: one ring does not rule them all. PLOS Genet. 15 (8): e1008373.

https://doi.org/10.1371/journal.pgen.1008373

Kreplak K, Madoui M-A, Cápal P, Novák P, Labadie K, Aubert G, Bayer PE, Gali KK, Syme RA, Main D, Klein A, Bérard A, Vrbová I, Fournier C, d'Agata L, Belser C, Berrabah W, Toegelová H, Milec Z, Vrána J, Lee H, Kougbeadjo A, Térézol M, Huneau C, Turo CJ, Mohellibi N, Neumann P, Falque M, Gallardo K, McGee R, Tar'an B, Bendahmane A, Aury JM, Batley J, Le Paslier MC, Ellis N, Warkentin TD, Coyne CJ, Salse J, Edwards D, Lichtenzveig J, Macas J, Doležel J, Wincker P, Burstin J (2019) A reference genome for pea provides insight into legume genome evolution. Nature Genet. 51: 1411-1422.

https://doi.org/10.1038/s41588-019-0480-1

Larkin, M.A., Blackshields, G., Brown, N.P., Chenna, R., McGettigan, P.A., McWilliam, H., Valentin, F., Wallace, I.M., Wilm, A., Lopez, R., Thompson, J.D., 
Gibson, T.J., Higgins, D.G. 2007. Clustal W and Clustal X version 2.0.

Bioinformatics. 23, 2947-2948. https://doi.org/10.1093/bioinformatics/btm404

Loenning, W.-E. 1984. Cross fertilization in peas under different ecological conditions. Pisum Newsletter. 16, 38-40.

Maxted, N. Ambrose, M. 2001. Peas (Pisum L.). In: Plant genetic resources of legumes in the Mediterranean. Eds. Maxted N. and S.J. Bennett. Kluwer Academic Publishers. The Netherlands. Chapter 10, pp 181-190.

Maxted, N., Kell, S.P. 2009. Establishment of a global network for the in situ conservation of crop wild relatives: status and needs. FAO Commission on Genetic Resources for Food and Agriculture. Rome.

Milne, I., Stephen, G., Bayer, M., Cock, P.J.A., Pritchard, L., Cardle, L., Shaw, P.D., Marshall, D. 2013 Using Tablet for visual exploration of second-generation sequencing data. Briefings in Bioinformatics. 14, 193-202. https://doi.org/10.1093/bib/bbs012

Muehlbauer, F.J., Kaiser, W.J., Kutlu, Z., Sperling, C.R. 1990. Collection of Pisum germplasm in Turkey in 1985 and 1989. Pisum Genetics. 22, 98-99.

Palmer, J.D., Jorgensen, R.A., Thompson, W.F. 1985. Chloroplast DNA variation and evolution in Pisum: patterns of change and phylogenetic analysis. Genetics. 109, 195-213. PMCID: PMC1202476

Schaefer, H., Hechenleitner, P., Santos-Guerra, A., Menezes de Sequeira, M., Pennington, R.T., Kenicer, G., Carine, M.A. 2012. Systematics, biogeography, and character evolution of the legume tribe Fabeae with special focus on the middleAtlantic island lineages. BMC Evol Biol. 12, 250. https://doi.org/10.1186/14712148-12-250

Shatskaya, N.V., Bogdanova, V.S., Kosterin, O.E., Vasiliev, G.V., Kimeklis, A.K., Andronov, E.E., Provorov, N.A. 2019. The plastid and mitochondrial genomes of Vavilovia formosa (Stev.) Fed. and the phylogeny of related legume genera. Vavilovskii Zhurnal Genetiki i Selektsii $=$ Vavilov Journal of Genetics and Breeding 23 (8), 972-980. https://doi.org/10.18699/VJ19.574.

Siniauskaya, M.G., Makarevich, A.M., Goloenko, I.M., Pankratov, V.S., Liaudanski, A.D., Danilenko, N.G., Lukhanina, N.V., Shimkevich A.M., Davydenko, O.G. 2020. The study of organelle DNA variability in alloplasmic barley lines in the NGS era. Vavilovskii Zhurnal Genetiki i Selektsii = Vavilov Journal of Genetics and Breeding 24 (1), 12-19. https://doi.org/10.18699/VJ19.589

Sloan, D.B., Alverson, A.J., Chuckalovcak, J.P., Wu, M., McCauley, D.E., Palmer, J.D., Taylor, D.R. 2012. Rapid evolution of enormous, multichromosomal genomes in flowering plant mitochondria with exceptionally high mutation rates. PLoS Biology 10 (1): e1001241. https://doi.org/10.1371/journal.pbio.100124.

Smith, D.R., Keeling, P.J. 2015. Mitochondrial and plastid genome architecture: reoccurring themes, but significant differences at the extremes. Proc. Natl. Acad. Sci. USA 112 (33): 10177-10184. https://doi.org/10.1073/pnas.1422049112.

Smýkal, P., Trněný, O., Brus, J., Hanáček, P., Rathore, A., Roma, R.D., Pechanek, V., Douchoslav, M., Battacharrya, D., Bariotakis M., Pirintsos, S., Berger, J., Toker, C. 2018. Genetic structure of wild pea (Pisum sativum subsp. elatius) populations in the northern part of the Fertile Crescent reflects moderate cross-pollination and 
strong effect of geographic but not environmental distance. PLoS ONE 13(3), e0194056. https://doi.org/10.1371/journal.pone.0194056

Smýkal, P.,Hradilová I., Trněný, O., Brus, J., Rathore, A., Bariotakis, M., Das, R.R., Bhattacharyya, D., Richards, C., Coyne, C.J.. Pirintsos, S. 2017. Genomic diversity and macroecology of the crop wild relatives of domesticated pea. Scientific Reports 7, 17384. https://doi.org/10.1038/s41598-017-17623-4

Tamura, K., Stecher, G., Peterson, D., Kumar, S. 2013. MEGA6: molecular evolutionary genetics analysis version 6.0. Mol. Biol. Evol. 30, 2725-2729. https://doi.org/10.1093/molbev/mst197

Tar'an, B., Zhang, C., Warkentin, T., Tullu, A., Vandenberg, A. 2005. Genetic diversity among varietis and wild species accessions of pea (Pisum sativum L.) based on molecular markers, and morphological and physiological characters. Genome. 48, 257-272. https://doi.org/10.1139/g04-114

Van de Paer, C., Bouchez, R., Besnar, G. 2017. Prospect of evolutionary mitogenomics of plants: a case study of the olive family (Oleaceae). Mol. Ecol. Resour. 2017: 1-17. https://doi.org/10.1111/1755-0998.12742

Vershinin, A.V., Allnutt, T.R., Knox, M.R., Ambrose, M.J., Ellis, T.H.N.. 2003. Transposable elements reveal the impact of introgression rather than transposition, in Pisum diversity, evolution and domestication. Mol. Biol. Evol. 20, 2067-2075. https://doi.org/10.1093/molbev/msg220

Vishnyakova, M. 2020. The Vavilov's Institute (VIR) contribution to the survey and study of Vavilovia formosa (Fabaceae). Bio. Comm. 65 (1), 28-40. https://doi.org/10.21638/spbu03.2020.103

Weeden, N.F. 2007. Genetic changes accompahying the domestication of Pisum sativum: is there a common genetic basis to the 'domestication syndrome' for legumes? Ann. Bot. 100, 1017-1025.

Weeden, N. 2018. Domestication of pea (Pisum sativum L.): the case of the Abyssinian Pea. Frontiers Plant Sci. 9, 515. https://doi.org/10.3389/fpls.2018.00515

Zaytseva, O.O., Bogdanova, V.S, Kosterin, O.E. 2012. Phylogenetic reconstruction at the species and intraspecies levels in the genus Pisum (L.) (peas) using a histone H1 gene. Gene. 504, 192-202.

https://doi.org/10.1016/j.gene.2012.05.026

Zaytseva, O.O., Gunbin, K.V., Mglinets, A.V., Kosterin, O.E. 2015. Divergence and population traits in evolution of the genus Pisum L. as reconstructed using genes of two histone $\mathrm{H} 1$ subtypes showing different phylogenetic resolution. Gene. 556, 235-244. https://doi.org/10.1016/j.gene.2014.11.062

Zaytseva O.O., Bogdanova V.S., Mglinets A.V., Kosterin O.E. 2017. Refinement of the collection of wild peas (Pisum L.) and search for the area of pea domestication with a deletion in the plastidic $p s b A$-trnH spacer. Genetic Resources and Crop Evolution. 64 (6), 1417-1430. https://doi.org/10.1007/s10722-016-0446-4

Zohary, D., Hopf, M. 2000. Domestication of Plants in the Old World, 3rd ed. Clarendon Press, Oxford. 